\title{
Performance \\ Assessment of Example PVT-Systems
}
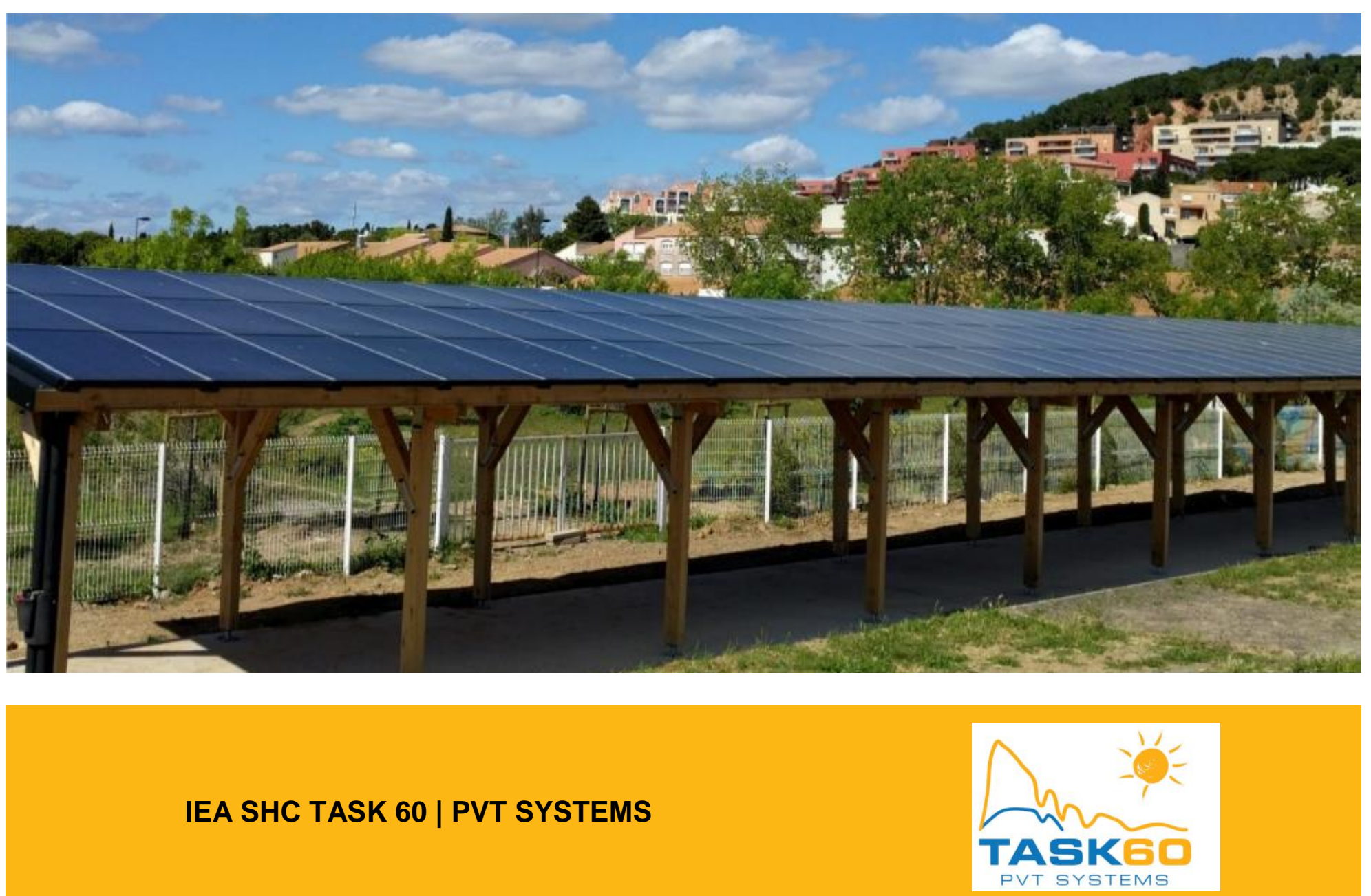


\section{Performance Assessment of Example PVT- Systems}

\section{SHC Task 60/Report D2}

Main Authors: Maike Schubert and Daniel Zenhäusern, SPF Institute for Solar Technology, OST University of Applied Sciences, Rapperswil, Switzerland

Contributors (in alphabetical order):

Alexander Mellor (Naked Energy)

Antonio Gagliano (UNICT)

Carsten Corino (Sunoyster)

Daniel Zenhäusern (SPF)

Diogo Cabral (Solarus)

Glen Ryan (Sunovate)

Guiseppe Marco Tina (UNICT)

Isabel Guedea (EndeF)

Jürg Rohrer (ZHAW)

Laetitia Brottier (DualSun)

Maike Schubert (SPF)

Manuel Lämmle (Fraunhofer ISE)

Marco Pellegrini (UNIBO)

Mark Dannemand (DTU)

Marta Cañada (Abora Solar)

Niels Radisch (Ramboll)

Nikola Pokorny (UCEEB CTU)

Date: November $5^{\text {th }}, 2020$

Report number: D2

DOI: 10.18777/ieashc-task60-2020-0009

Front page: PVT-canopy for muncipial swimming pool in Sète. Picture by DualSun.

The contents of this report do not necessarily reflect the viewpoints or policies of the International Energy Agency (IEA) or its member countries, the IEA Solar Heating and Cooling Technology Collaboration Programme (SHC TCP) members or the participating researchers. 
IEA Solar Heating and Cooling Technology Collaboration Programme (IEA SHC)

The Solar Heating and Cooling Technology Collaboration Programme was founded in 1977 as one of the first multilateral technology initiatives ("Implementing Agreements") of the International Energy Agency. Its mission is "To enhance collective knowledge and application of solar heating and cooling through international collaboration to reach the goal set in the vision of solar thermal energy meeting $50 \%$ of low temperature heating and cooling demand by 2050."

The members of the IEA SHC collaborate on projects (referred to as Tasks) in the field of research, development, demonstration (RD\&D), and test methods for solar thermal energy and solar buildings.

Research topics and the associated Tasks in parenthesis include:

- $\quad$ Solar Space Heating and Water Heating (Tasks 14, 19, 26, 44, 54)

- Solar Cooling (Tasks 25, 38, 48, 53, 65)

- Solar Heat for Industrial or Agricultural Processes (Tasks 29, 33, 49, 62, 64)

- Solar District Heating (Tasks 7, 45, 55)

- Solar Buildings/Architecture/Urban Planning (Tasks 8, 11, 12, 13, 20, 22, 23, 28, 37, 40, 41, 47, 51, 52, $56,59,63)$

- $\quad$ Solar Thermal \& PV (Tasks 16, 35, 60)

- $\quad$ Daylighting/Lighting (Tasks 21, 31, 50, 61)

- Materials/Components for Solar Heating and Cooling (Tasks 2, 3, 6, 10, 18, 27, 39)

- Standards, Certification, and Test Methods (Tasks 14, 24, 34, 43, 57)

- $\quad$ Resource Assessment (Tasks 1, 4, 5, 9, 17, 36, 46)

- $\quad$ Storage of Solar Heat (Tasks 7, 32, 42, 58)

In addition to our Task work, other activities of the IEA SHC include our:

$>$ International Conference on Solar Heating and Cooling for Buildings and Industry

$>$ SHC Solar Academy

$>$ Solar Heat Worldwide annual statics report

> Collaboration with solar thermal trade associations

\section{Country Members}

$\begin{array}{lll}\text { Australia } & \text { France } & \text { South Africa } \\ \text { Austria } & \text { Germany } & \text { Spain } \\ \text { Belgium } & \text { Italy } & \text { Sweden } \\ \text { Canada } & \text { Netherlands } & \text { Switzerland } \\ \text { China } & \text { Norway } & \text { Turkey } \\ \text { Denmark } & \text { Portugal } & \text { United Kingdom } \\ \text { European Commission } & \text { Slovakia } & \end{array}$

\section{Sponsor Members}

European Copper Institute

EACREEE 


\section{Contents}

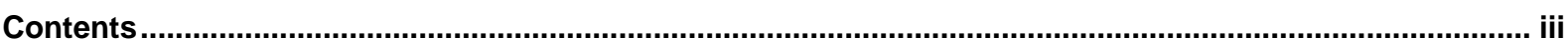

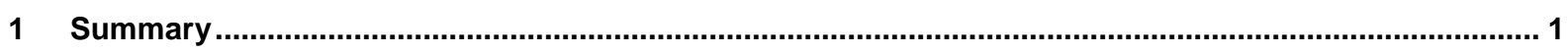

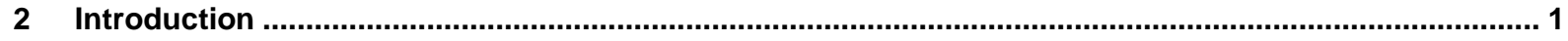

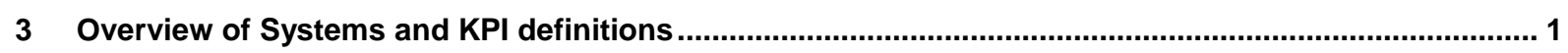

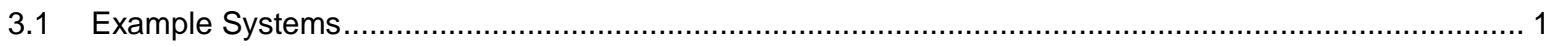

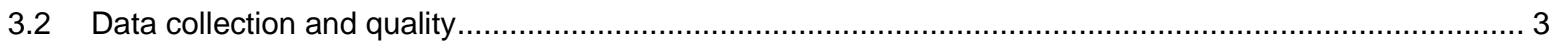

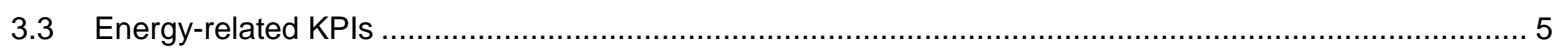

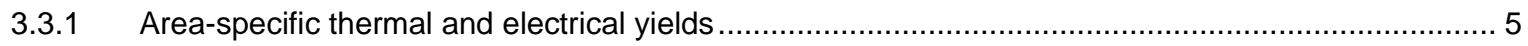

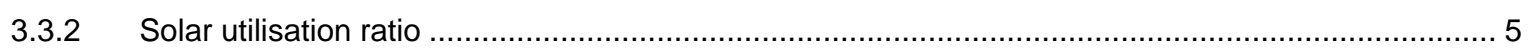

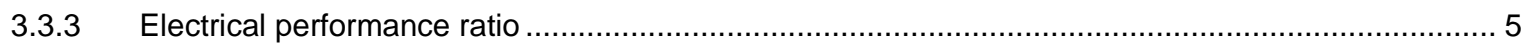

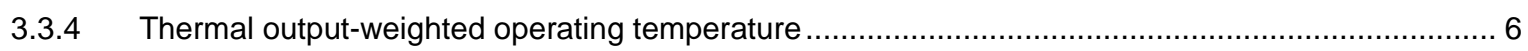

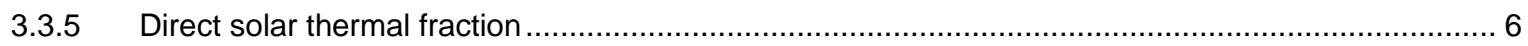

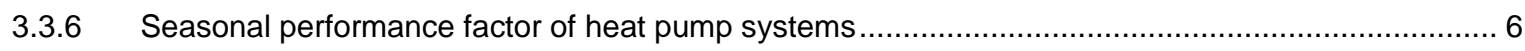

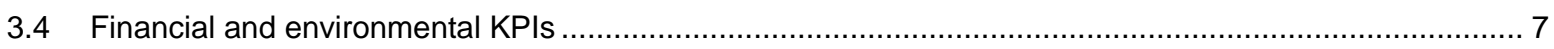

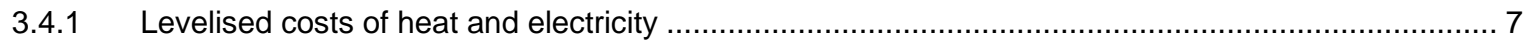

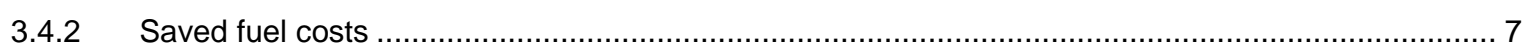

3.4.3 Avoided global warming potential and primary energy consumption ...................................... 7

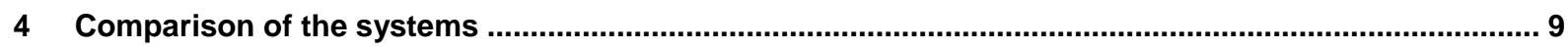

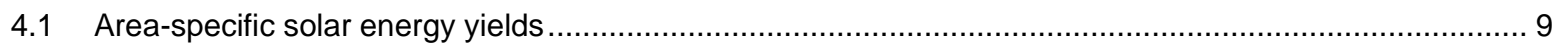

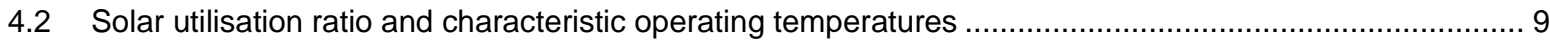

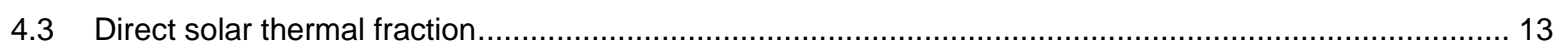

4.4 Seasonal performance factor of heat pump systems ............................................................. 13

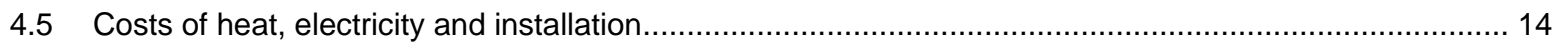

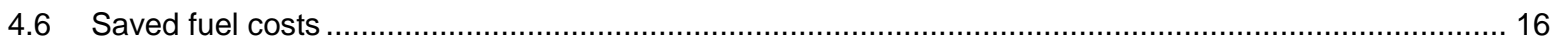

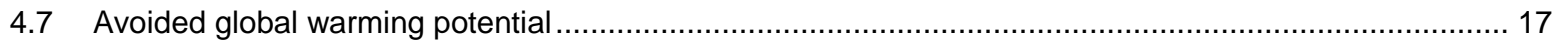

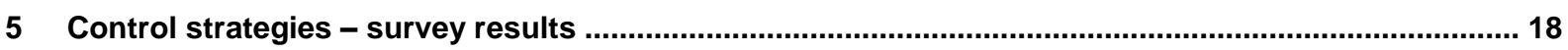

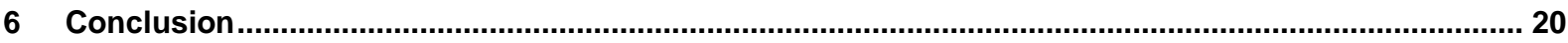

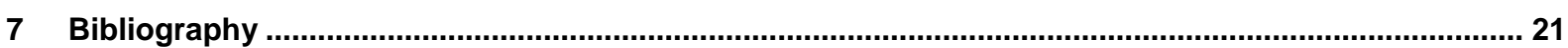




\section{Summary}

The performance of 26 PVT-Systems was analysed and compared in IEA-SHC Task 60 . The systems are located in countries with different climatic conditions. The applications range from direct domestic hot water production and heating of public swimming pools to heat pump systems with PVT as the main heat source of the heat pump. The Key Performance Indicators (KPIs) determined for the different PVT solutions give the possibility to compare the systems despite their diversity. The goal was to show the potential of PVT collectors in different fields of application. The results show that the integration of PVT collectors in different kinds of well-dimensioned systems leads to competitive solutions, both from an energy and a financial perspective. Additionally the answers to a survey about control strategies for PVT systems, showing some main problems and possible solutions, are summarised.

\section{Introduction}

In this report, the performance of a number of PVT systems in operation, which are described in detail in Subtask A report A1 of Task 60, is assessed and compared in terms of several Key Performance Indicators (KPIs). These energy-related, financial and environmental KPIs are a selection of the performance indicators defined in Subtask $D$ report D1. The performance of a PVT system always depends on a number of factors, in particular on the type of collectors used, the way the collectors are integrated to the system, the local heat and electricity demands and the climatic conditions of the site, i.e. solar irradiation, ambient temperature and wind. The large number of known and sometimes unknown influencing factors makes a completely fair comparison very difficult. Nevertheless, the KPIs are defined such as to make some key aspects of the system performance comparable.

\section{Overview of Systems and KPI definitions}

\subsection{Example Systems}

All Systems analysed are listed in Table 1 together with some information on their type and situation. A detailed description of the systems is provided in Subtask A Report A1 (Thomas Ramschak et al. 2020). The systems are very diverse, with different collector types (uncovered, covered, evacuated tube and concentrating collector), different applications of the solar heat (e.g. domestic hot water preparation, space heating, pool heating, and ground source regeneration), and also very different climatic conditions. Most systems use PVT collectors running with a Water/Glycol mixture as heat transfer fluid. Only one system uses PVT collectors with air as the heat transfer medium. As an example for the diversity of the analysed systems, Figure 1 shows two examples: Evacuated tube PVT-collectors producing heat for a cheese factory on the left and in-roof, uncovered PVT collectors as source of a heat pump in a multi-family building on the right. 

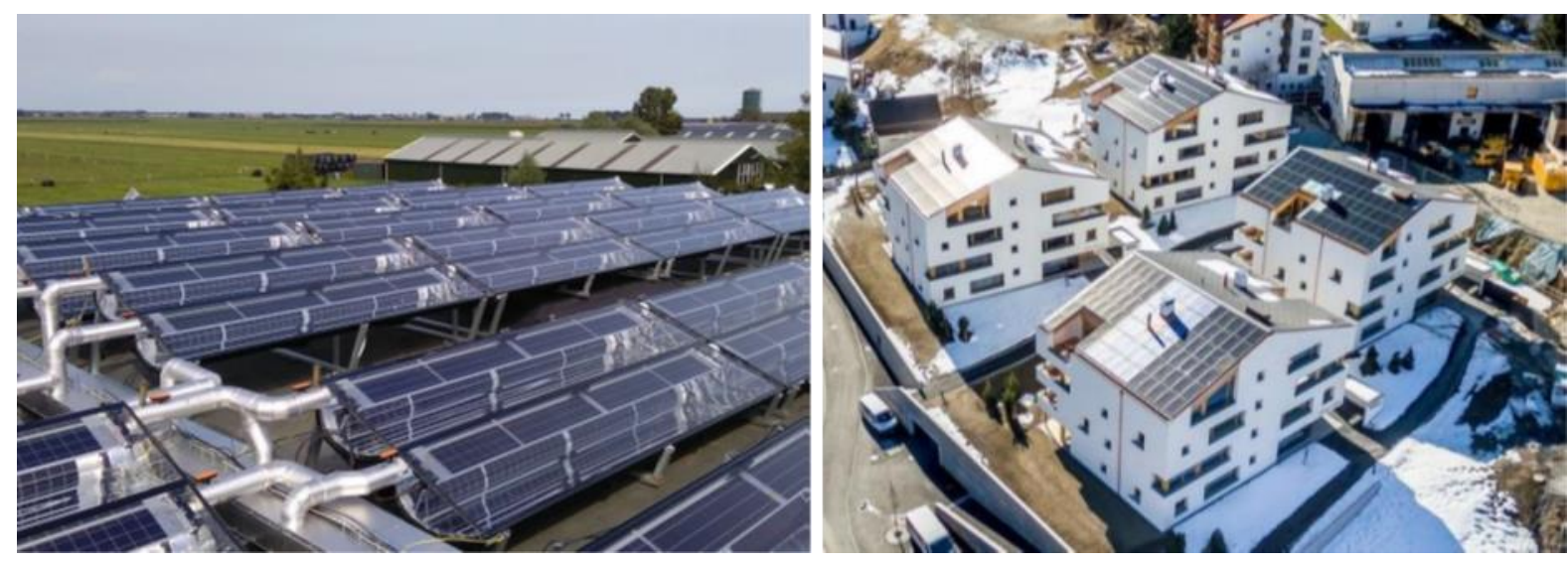

Figure 1: Example Pictures of PVT-Systems, left: cheese factory Katwoude, right: multi family buildings in Scoul.

Table 1: Overview of PVT installations collected in Task 60. The applications are divided into five categories: DHW: PVT heat is used for domestic hot water directly; DHW, SH: PVT heat used for domestic hot water and space heating; DHW, pool: PVT heat is used for domestic hot water and pool heating; HP: PVT collectors as source for a heat pump or for regeneration of a ground source (boreholes); DHW-HP: PVT heat is used directly for producing domestic hot water and also as a source for a heat pump. Systems 8 and 9 are not within one of those categories. In system 8 the PVT heat supplies heat for cheese production. In system 9, PVT collectors provide heat for domestic hot water as well as for regeneration of boreholes.

\begin{tabular}{|c|c|c|c|c|c|}
\hline $\begin{array}{c}\text { System } \\
\mathrm{Nr}\end{array}$ & Country & City & Application & Collector Type & $\begin{array}{c}\text { Gross } \\
\text { collector } \\
\text { area }\left(m^{2}\right)\end{array}$ \\
\hline 1 & ESP & Zaragoza & DHW & covered & 30 \\
\hline 2 & ESP & Zaragoza & $\mathrm{DHW}, \mathrm{SH}$ & covered & 10 \\
\hline 3 & ESP & Ibiza & DHW & covered & 148 \\
\hline 4 & ESP & Zaragoza & DHW, pool & covered & 46 \\
\hline 5 & ITA & Catania & DHW & uncovered & 3 \\
\hline 6 & $\mathrm{CHE}$ & Näfels & $\mathrm{HP}$ & uncovered & 292 \\
\hline 7 & DNK & Egedal & DHW, SH & uncovered & 80 \\
\hline 8 & NLD & Katwoude & others & covered & 226 \\
\hline 9 & CZE & Prerov & others & uncovered & 188 \\
\hline 10 & ITA & Suello & $\mathrm{HP}$ & uncovered & 26 \\
\hline 11 & DEU & Freiburg & DHW & covered & 48 \\
\hline 12 & DEN & Kgs. Lyngby & DHW & uncovered & 3 \\
\hline 13 & $\mathrm{CHE}$ & Wettswil am Albis & $\mathrm{HP}$ & uncovered & 50 \\
\hline 14 & $\mathrm{CHE}$ & Ostermundigen & $\mathrm{HP}$ & uncovered & 622 \\
\hline 15 & $\mathrm{CHE}$ & Rapperswil & DHW & uncovered & 10 \\
\hline 16 & $\mathrm{CHE}$ & Obfelden & DHW & uncovered & 423 \\
\hline 17 & $\mathrm{CHE}$ & Scuol & $\mathrm{HP}$ & uncovered & 130 \\
\hline 18 & FRA & Amberieu-En-Bugey & DHW & uncovered & 6 \\
\hline 19 & FRA & Saint-Genis-Les-Ollieres & DHW & uncovered & 10 \\
\hline 20 & FRA & Sete & DHW, pool & uncovered & 300 \\
\hline 21 & FRA & Perpignan & DHW, pool & uncovered & 300 \\
\hline 22 & AUS & $\begin{array}{l}\text { South Perth Western } \\
\text { Australia }\end{array}$ & $\mathrm{DHW}, \mathrm{SH}$ & air & 8 \\
\hline 23 & GBR & Swansea & DHW, SH & evacuated tube & 27 \\
\hline 24 & GER & Enge-Sande & $\mathrm{DHW}, \mathrm{SH}$ & concentrating & n.a. \\
\hline 25 & FRA & Lyon & DHW & uncovered & 9.5 \\
\hline 26 & FRA & Carquefou & HP & uncovered & 149 \\
\hline
\end{tabular}




\subsection{Data collection and quality}

The data for the PVT example cases were collected within Task 60. As the systems had been monitored for different reasons, not all data are available for all systems and hence not all KPIs could be computed for every system. Therefore, the comparisons of cases presented in the following sections, do not in general include all systems, but only those for which the respective KPI is meaningful and available. For calculating the direct solar thermal fraction for systems with direct use of solar heat the thermal yield to primary side is given in Table 2.

Table 2: Overview of the measurement values of the PVT-systems used for KPI calculation. Red values indicate missing measured values. For the transition between $A C$ and DC yield, the inverter efficiency was assumed to be 0.95. Investment costs for the thermal part are assumed to be $2 / 3^{\text {rds }}$ of the total investment costs of the PVTSystem if no value was available. Irradiation data in red indicate missing measurement values, they were replaced by Meteonorm 7 (www.meteonorm.com) values for a typical year and the given location. *) For system 12 the measurement period is shorter than 1 year.

\begin{tabular}{|c|c|c|c|c|c|c|c|}
\hline $\begin{array}{l}\text { System } \\
\mathrm{Nr}\end{array}$ & $\begin{array}{l}\text { el. yield } \\
\text { DC (kWh) }\end{array}$ & $\begin{array}{l}\text { el. yield } \\
\text { AC (kWh) }\end{array}$ & $\begin{array}{l}\text { thermal } \\
\text { yield (kWh) }\end{array}$ & $\begin{array}{l}\text { thermal yield } \\
\text { to primary } \\
\text { side (kWh) }\end{array}$ & $\begin{array}{l}\text { investment } \\
\text { costs } \\
\left(E U R / m^{2}\right)\end{array}$ & $\begin{array}{l}\text { Investment } \\
\text { costs } \\
\text { thermal } \\
(\text { EUR/m²) }\end{array}$ & $\begin{array}{l}\text { Irradiation } \\
\text { on collector } \\
\text { plane } \\
\left(\mathbf{k W h} / \mathbf{m}^{2}\right)\end{array}$ \\
\hline 1 & $5 ' 160$ & 4'902 & $18^{\prime} 004$ & $18 ’ 004$ & $1 ' 111$ & 740 & 1902 \\
\hline 2 & $1^{\prime} 647$ & 1'565 & 7'166 & 7'166 & & & 1710 \\
\hline 3 & $31^{\prime} 528$ & 29'952 & $101^{\prime} 310$ & $101 ' 310$ & & & 1863 \\
\hline 4 & 9'618 & 9'137 & $25 ’ 449$ & $25^{\prime} 449$ & 909 & 606 & 1898 \\
\hline 5 & 930 & 890 & 1'450 & 1'400 & 4'518 & 3'012 & 1700 \\
\hline 6 & 56,015 & $48 ' 709$ & $129^{\prime} 000$ & $42 ' 500$ & 1'276 & 849 & 1214 \\
\hline 7 & $27^{\prime} 200$ & $25^{\prime} 840$ & $12^{\prime} 000$ & $12 ’ 000$ & 1'688 & 1'125 & 1182 \\
\hline 8 & $15^{\prime} 634$ & $14 ’ 852$ & $533^{\prime} 687$ & $533^{\prime} 687$ & 360 & 240 & 1062 \\
\hline 9 & $30 ’ 513$ & $28^{\prime} 987$ & $22 ’ 085$ & $22 ’ 085$ & 859 & 573 & 1243 \\
\hline 10 & 5'200 & 4'940 & $166^{\prime} 320$ & $16 ’ 320$ & 1'495 & 997 & 1543 \\
\hline 11 & 6348 & 6031 & 4'743 & 4'743 & & & 1233 \\
\hline 12 & 237 & 225 & 1'110 & 15 & 1'355 & 720 & $745^{*}$ \\
\hline 13 & 5’554 & 5'276 & $12^{\prime} 255$ & 4'534 & & & 1179 \\
\hline 14 & $98 ' 211$ & 93 '300 & $195 ' 800$ & 0 & 1'286 & 857 & 1230 \\
\hline 15 & $1 ’ 742$ & 1'655 & 2'762 & 2'762 & & & 1425 \\
\hline 17 & 20’396 & $19 ’ 376$ & 16 '335 & 3'230 & 1'647 & 787 & 1428 \\
\hline 18 & 1'053 & 1'000 & 300 & 300 & 1'047 & 698 & 1400 \\
\hline 19 & 1'842 & $1 ' 750$ & 410 & 410 & 1'042 & 694 & 1460 \\
\hline 20 & $62 ' 226$ & $59 ' 115$ & $82 ' 100$ & $82 ' 100$ & 1'167 & 778 & 1677 \\
\hline 21 & 67’305 & $63 ' 940$ & $119^{\prime} 870$ & $119^{\prime} 870$ & 1'167 & 778 & 1610 \\
\hline 23 & 2'080 & 1'976 & $5^{\prime} 640$ & $5^{\prime} 640$ & & & 1200 \\
\hline 25 & 2’010 & 1'910 & 2'130 & 2'130 & $1 ' 058$ & 515 & 1413 \\
\hline 26 & $31^{\prime} 445$ & $29 ' 873$ & $41^{\prime} 841$ & - & 605 & 385 & 1438 \\
\hline
\end{tabular}

Some KPIs involve the solar irradiance at the plant location. As for many example systems, the global solar irradiance was not measured, global irradiance data for a typical year in the collector-plane from Meteonorm 7 (www.meteonorm.com) are used for these systems (indicated in red in Table 2). This leads to a considerable uncertainty, because the irradiation in a particular year can differ significantly from a typical year. The geographical horizon is considered in the data, the local horizon due to neighbouring buildings or trees cannot be considered. 
The operation temperature of the PVT collectors has a significant influence on the yields of the PVT System. Reliable fluid temperatures were available for 11 systems. Reliable values for the costs of the PVT-Systems were available for 15 systems. Electricity tariffs and given or assumed self-consumption fraction and the costs for fuel replaced are given in Table 3: Electricity tariffs and measured or assumed values for the self-consumption fraction. Table 3.

Table 3: Electricity tariffs and measured or assumed values for the self-consumption fraction.

\begin{tabular}{|c|c|c|c|c|c|c|}
\hline System Nr & Country & $\begin{array}{l}\text { Local feed-in } \\
\text { tarif } \\
\text { (EUR/kWh) }\end{array}$ & $\begin{array}{l}\text { Local electricity } \\
\text { retail price }\end{array}$ & $\begin{array}{l}\text { Solar } \\
\text { electricity } \\
\text { self- } \\
\text { consumption } \\
\text { fraction }\end{array}$ & $\begin{array}{l}\text { Type of final } \\
\text { energy } \\
\text { replaced }\end{array}$ & $\begin{array}{l}\text { Cost of fuel } \\
\text { replaced } \\
\text { (EUR/MWh) }\end{array}$ \\
\hline 1 & ESP & 0.118 & 0.150 & 0.20 & gas & 30 \\
\hline 2 & ESP & 0.118 & 0.150 & 0.20 & gas & 30 \\
\hline 3 & ESP & 0.118 & 0.150 & 0.20 & fuel & 36 \\
\hline 4 & ESP & 0.118 & 0.150 & 0.20 & gas & 30 \\
\hline 5 & ITA & 0.100 & 0.150 & 0.20 & electricity & 250 \\
\hline 6 & $\mathrm{CHE}$ & 0.165 & 0.150 & 0.00 & electricity & \\
\hline 7 & DNK & 0.000 & 0.150 & 0.20 & electricity & 200 \\
\hline 8 & NLD & 0.190 & 0.150 & 0.20 & electricity & 82 \\
\hline 9 & CZE & & 0.150 & 0.20 & - & - \\
\hline 10 & ITA & 0.022 & 0.150 & 0.20 & electricity & 22 \\
\hline 11 & DEU & 0.100 & 0.150 & 0.20 & - & - \\
\hline 12 & DEN & 0.050 & 0.310 & 0.30 & electricity & 68 \\
\hline 13 & $\mathrm{CHE}$ & 0.068 & 0.159 & 0.20 & electricity & - \\
\hline 14 & $\mathrm{CHE}$ & 0.081 & 0.234 & 0.20 & electricity & - \\
\hline 15 & $\mathrm{CHE}$ & 0.098 & 0.185 & 0.20 & gas & 60 \\
\hline 17 & $\mathrm{CHE}$ & 0.039 & 0.157 & 0.30 & electricity & - \\
\hline 18 & FRA & 0.060 & 0.150 & 0.20 & gas & 80 \\
\hline 19 & FRA & 0.060 & 0.150 & 0.20 & gas & 80 \\
\hline 20 & FRA & 0.131 & 0.150 & 0.20 & gas & 60 \\
\hline 21 & FRA & 0.131 & 0.150 & 0.20 & gas & 60 \\
\hline 23 & GBR & & 0.150 & 0.20 & - & - \\
\hline 25 & FRA & 0.100 & 0.173 & 0.61 & electricity & 173 \\
\hline 26 & FRA & 0.060 & 0.120 & 1.00 & - & 60 \\
\hline
\end{tabular}

A detailed description of KPIs useful for PVT systems and the used notation is given in Report D1 (Daniel Zenhäusern et al., in prep.). The KPIs used here for the evaluation of the example systems are shown in Table 4.and described briefly in the following sections. 
Table 4: Overview of the KPIs selected for the comparison of the example systems in the three categories Energyrelated, Financial and Environmental.

\begin{tabular}{|c|c|}
\hline \multirow{5}{*}{ Energy } & Thermal and electrical solar yields per $\mathrm{m}^{2}$ \\
\hline & Thermal and electrical utilisation rations (yield/irradiation) \\
\hline & Output-weighted operating temperature \\
\hline & Solar thermal fraction \\
\hline & Seasonal performance factor (for heat pump systems) \\
\hline \multirow{3}{*}{ Economics } & Specific investment cost per $\mathrm{m}^{2}$ \\
\hline & Levelized cost of heat and electricity (LCOH, LCOE) \\
\hline & Saved fuel and grid electricity cost \\
\hline \multirow{2}{*}{ Environment } & Avoided primary energy depletion [kWh oil-eq/( $\left.\left.\mathrm{a}^{*} \mathrm{~m}^{2}\right)\right]$ \\
\hline & Avoided global warming impact [kg CO2-eq/(a* $\left.\left.\mathrm{m}^{2}\right)\right]$ \\
\hline
\end{tabular}

\subsection{Energy-related KPIs}

\subsubsection{Area-specific thermal and electrical yields}

For system comparison the thermal and electrical yields are frequently normalized to the gross area. Area-specific quantities like e.g. thermal and electrical yields which are used performance indicator, can be denoted by lower case letters as $q_{P V T}^{\text {gross }}=Q_{P V T} / A_{P V T}^{\text {gross }}$ and $e_{P V T}^{D C, \text { gross }}=E_{P V T}^{D C} / A_{P V T}^{g r o s s}$.

\subsubsection{Solar utilisation ratio}

The solar utilisation ratio describes the performance of a collector field over a specified period. Thermal utilisation ratio $\omega_{P V T, t h}^{g r o s s}$, the electrical utilisation ratio $\omega_{P V T, e l}^{D C, g r o s s}$ and the combined energy utilisation ratio $\omega_{P V T, \text { en }}^{D C, g r s}$ are defined as follows:

$$
\begin{aligned}
\omega_{P V T, t h}^{\text {gross }} & =\frac{Q_{P V T}}{\int G_{\text {col }} d t \cdot A_{P V T}^{\text {gross }}} \\
\omega_{P V T, \text { el }}^{D C, \text { gross }} & =\frac{E_{P V T}^{D C}}{\int G_{c o l} d t \cdot A_{P V T}^{g r o s s}} \\
\omega_{P V T, \text { en }}^{D C, \text { gross }} & =\frac{Q_{P V T}+E_{P V T}^{D C}}{\int G_{c o l} d t \cdot A_{P V T}^{g r o S s}}
\end{aligned}
$$

where $Q_{P V T}$ corresponds to the thermal energy output and $E_{P V T}^{D C}$ to the electrical energy output of the collector field, over the specified time period. $G_{c o l}$ is the global irradiance per $\mathrm{m}^{2}$ in the collector plane (typically integrated over a period of a year) and $A_{P V T}^{g r o s s}$ the gross area of the collector field.

\subsubsection{Electrical performance ratio}

For characterizing $\mathrm{PV}$ installations, the performance ratio $(P R)$ is used frequently, comparing the actual $\mathrm{AC}$ yield of the system with the nominal yield calculated using the global irradiance at the plant-location.

$$
P R_{P V T}=\frac{E_{P V T}^{A C}}{\int G_{c o l} d t \cdot A_{P V T}^{g r o s s} \cdot \eta_{P V T, e l}^{D C, g r o s s, S T C}}
$$


As $E_{P V T}^{A C}$ (electrical energy measured after the inverter) is used for calculating the performance ratio, it rates the whole system including inverter losses. The efficiency $\eta_{P V T, e l}^{D C, g r o s s, S T C}$ denotes the nominal efficiency of a PV-panel under standard testing conditions (STC, i.e. at a global solar irradiation of $1000 \mathrm{~W} / \mathrm{m}^{2}$ and a module temperature of $\left.25^{\circ} \mathrm{C}\right)$.

\subsubsection{Thermal output-weighted operating temperature}

Especially the thermal yield, but also the electrical yield depend on the operating temperature of the collector field. The characteristic temperature is an indicator for this temperature. Only by knowing such a temperature is one able to judge a value for an area-specific yield or a utilisation ratio, i.e. for example to tell if the yield of a collector field fulfils expectations. The characteristic operating temperature used here is defined as the weighted time average of the mean fluid temperature $\vartheta_{m}$ of the collector field, the weighting factor being the thermal collector field output $\dot{Q}_{P V T}$.

$$
\vartheta_{\text {charoutput }}^{m}=\frac{\int\left(\vartheta_{m} \cdot \dot{Q}_{P V T}\right) d t}{\int \dot{Q}_{P V T} d t}
$$

\subsubsection{Direct solar thermal fraction}

The direct solar thermal fraction is the proportion of the total heat provided by the heating system that is provided by the PVT-field. It is defined as follows:

$$
f_{\text {sol,th }}=\frac{Q_{P V T}^{(\text {direct })}}{Q_{\text {aux }, *}+Q_{P V T}^{(\text {direct })}},
$$

where $Q_{P V T}^{(\text {direct) }}$ denotes the amount of heat generated by the PVT-field and directly used in the system (typically for charging a heat storage tank ${ }^{1}$ ), $Q_{a u x, *}$ denotes the heat provided by any auxiliary heating (e.g. gas boiler, direct electrical, heat pump).

The local solar electrical fraction (self sufficiency) is defined as

$$
f_{\text {sol,el }}=\frac{E_{P V T, s y s}^{A C}+E_{P V T, H E}^{A C}}{E_{*, S y s}+E_{H E}},
$$

i.e. as the ratio between the solar electricity used locally (self-consumption) for the heating system, $E_{P V T, s y s}^{\mathrm{AC}}$, and for household electricity, $E_{P V T, H E}^{A C}$, and the total electricity consumption of the building, consisting of the electricity consumption of the heating system $E_{*, s y s}$ and the additional electricity consumption $E_{H E}$, typically of the households. Because hardly any data was available for the total electricity consumption of the heating system and of the households, it was not possible to compare the solar electrical fractions of the example systems.

\subsubsection{Seasonal performance factor of heat pump systems}

In combination with heat pumps the performance of PVT Systems can be assessed by using the seasonal performance factor for the heat pump system $S P F_{S H P+}$.

$$
S P F_{S H P+}^{(t o t a l)}=\left[\frac{Q_{u s e}+C_{u s e}}{E_{*, \text { sys }}}\right]_{S H P+}
$$

According to IEA-SHC Task 44 (Hadorn and Task 44 'Solar and Heat Pump Systems' (Project) 2015) the useful heat $Q_{u s e}$ and / or the useful cold $C_{u s e}$ is determined at the interfaces of the system with the heat/cold distribution and the hot water tap. $E_{*, \text { sys }}$, the consumed electricity includes electricity for all system components of the heating/cooling system.

\footnotetext{
1 This does not include, e.g., solar heat used for the regeneration of a ground source or as source of a heat pump.
} 


\subsection{Financial and environmental KPIs}

\subsubsection{Levelised costs of heat and electricity}

Levelised costs of energy describe the costs per kWh of energy produced in the system considering both investment and annual operation costs. It may be considered separately as levelised costs of heat $(\mathrm{LCOH})$ and levelised costs of electricity $(L C O E)$ :

$$
\begin{gathered}
L C O H=\frac{\left[I_{0}+\sum_{t=1}^{T=25} O M_{t} \cdot(1+r)^{-t}\right]_{\text {Solar thermal system components }}}{\sum_{t=1}^{T=25} Q_{P V T, t} \cdot(1+r)^{-t}} \\
L C O E=\frac{\left[I_{0}+\sum_{t=1}^{T=25}\left(O M_{t}\right) \cdot(1+r)^{-t}\right]_{\text {Solar electrical system components }}}{\sum_{t=1}^{T=25} E_{P V T, t}^{A C} \cdot(1+r)^{-t}}
\end{gathered}
$$

The costs for operation and maintenance $O M_{t}$ include investment, re- investment and annual costs over the assumed lifetime of the system ( $T=25$ years). As a default value $1 \%$ of the investment costs per year is assumed. $r$ is the real discount rate assumed to be $3 \%$.

\subsubsection{Saved fuel costs}

The saved fuel costs are calculated by the amount of heat replaced by solar thermal heat from the PVT and therefore does not need to be provided by an auxiliary fuel heater any more:

$$
C_{f u e l, \text { saved }}=\frac{Q_{P V T}}{\eta_{\text {burner }}} \cdot C_{\text {fuel }}
$$

The burner efficiency $\eta_{\text {burner }}$ is assumed to be $90 \%$ (upper heating value), $C_{\text {fuel }}$ was provided for the example systems in EUR/MWh and $Q_{P V T}$ refers to the thermal yield of the PVT plant. For heat pump systems, the avoided electricity is calculated as follows:

$$
C_{\text {el,saved }}=\frac{Q_{P V T}}{\operatorname{COP}_{H P}} \cdot C_{e l}
$$

The $C O P_{\mathrm{HP}}$ is assumed to be 3 for all heat pump systems, $C_{e l}$ is the local price for electricity.

\subsubsection{Avoided global warming potential and primary energy consumption}

The avoided environmental impact is calculated for global warming potential and fuel consumption as follows:

$$
\begin{gathered}
G W P_{\text {avoided }}=\frac{Q_{P V T}}{\eta_{\text {burner }}} \cdot G W P_{\text {fuel }}+E_{P V T}^{A C} \cdot F_{S C} \cdot G W P_{\text {elgrid }} \\
C E D n r_{\text {avoided }}=\frac{Q_{P V T}}{\eta_{\text {burner }}} \cdot C E D n r_{\text {fuel }}+E_{P V T}^{A C} \cdot F_{S C} \cdot C E D n r_{\text {elgrid }}
\end{gathered}
$$

with the electrical self-consumption fraction $F_{S C}=\left(E_{P V T, s y s}^{A C}+E_{P V T, H E}^{A C}\right) / E_{P V T}^{A C}$. It was assumed to be $20 \%$. The used CEDnr and GWP values for the different types of primary energy are listed in Table 5 . For heat pump systems the burner efficiency $\eta_{\text {burner }}$ refers to the COP of the heat pump and is assumed to be 3 . The $G W P_{\text {fuel }}$ and $C E D n r_{\text {fuel }}$ for electricity (ENTSO-E mix) are used for heat pump systems. 
Table 5: Cumulated non-renewable primary energy demand CEDnr and global warming potential (GWP) factors for different final energy carriers. * values from the Swiss "KBOB-list" (Koordinationskonferenz der Bau- und Liegenschaftsorgane der öffentlichen Bauherren KBOB 2016), European electricity mix ENTSO-E is used.

\begin{tabular}{|l|c|c|}
\hline & \multicolumn{1}{|c|}{ CEDnr } & GWP \\
\hline & kWh oil-eq & $\mathrm{kg} \mathrm{CO}_{2}$-eq \\
\hline $\begin{array}{l}\text { Oil }^{*} \text { (kWh upper } \\
\text { heating value) }\end{array}$ & 1.23 & 0.301 \\
\hline $\begin{array}{l}\text { Gas* (kWh upper } \\
\text { heating value) }\end{array}$ & 1.06 & 0.228 \\
\hline $\begin{array}{l}\text { Grid electricity* } \\
\text { (ENTSO-E; kWh } \\
\text { AC electricity) }\end{array}$ & 2.89 & 0.524 \\
\hline
\end{tabular}




\section{Comparison of the systems}

\subsection{Area-specific solar energy yields}

Figure 2 shows the area-specific thermal and electrical yields for all the example systems. There are large differences in the thermal yield between different systems. The reasons for these differences are diverse. For instance, all systems with covered collectors (except system 11) are located in places with particularly high yearly solar irradiation. Systems 18 and 19 have particularly low thermal yield as they are holiday houses that are only in use a few weeks per year. System 11 is a similar case, the assumed heat demand for domestic hot water used for the dimensioning of the PVT plant was 5 times higher than the real demand.

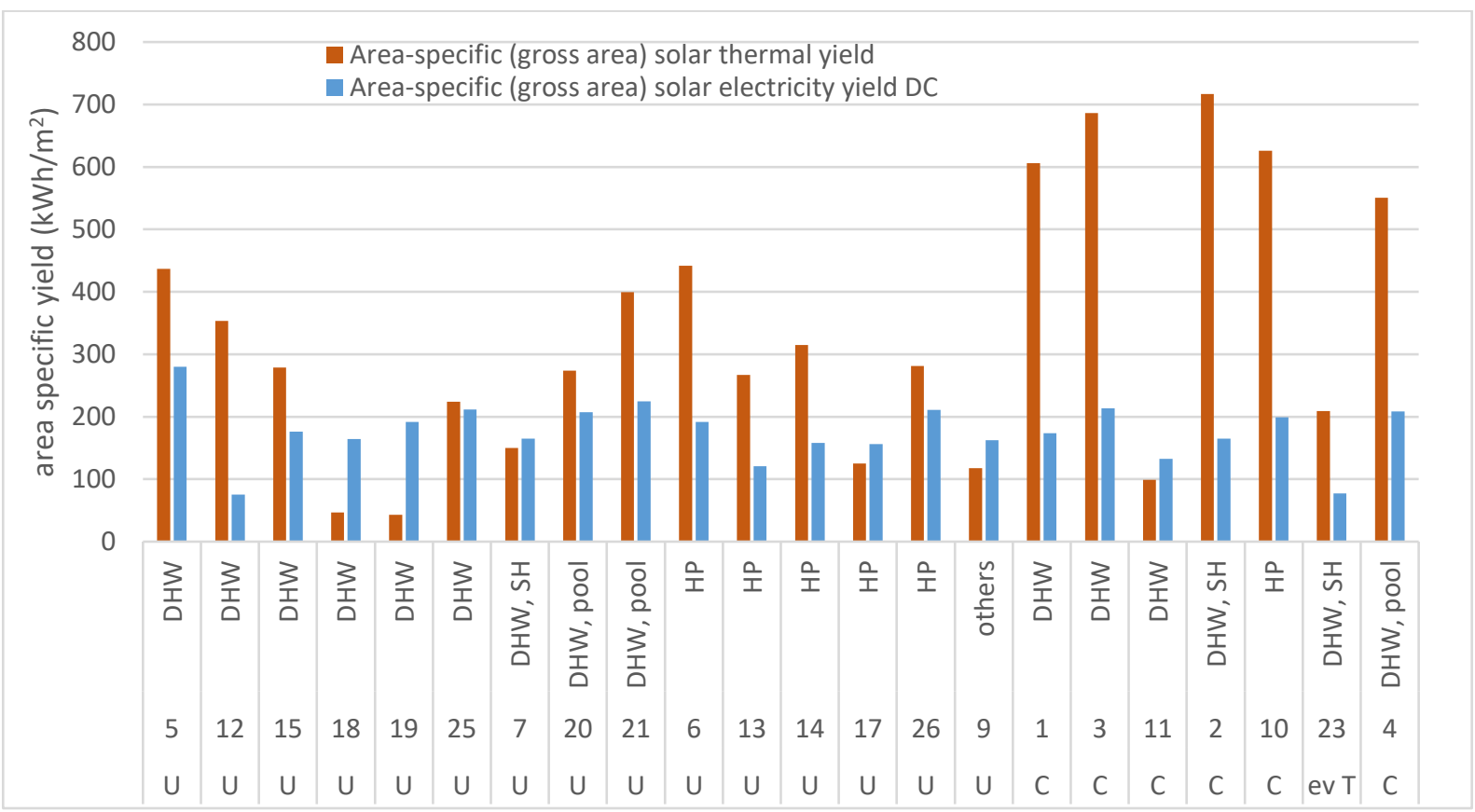

Figure 2: area specific yield from the PVT plant for the example systems. The numbers on the $x$-axis label indicates the system number. U: uncovered PVT collectors, C: covered PVT collectors, con: concentrating collector (Solarus), ev T: evacuated tube PVT collectors.

For comparison to conventional solar-thermal systems for domestic hot water preparation in Europe an annual area specific thermal yield of $420 \mathrm{kWh} / \mathrm{m}^{2}$ (DHW, average installation size $5.7 \mathrm{~m}^{2}$ ) can be assumed for Switzerland, 660 $\mathrm{kWh} / \mathrm{m}^{2}$ (DHW, average installation size $4 \mathrm{~m}^{2}$ ) for Italy, $500 \mathrm{kWh} / \mathrm{m}^{2}$ (DHW, average installation size $\left.3.2 \mathrm{~m}^{2}\right)$ for France (Weiss and Spörk-Dür 2020). In these data, different types of collectors are not considered separately, but only different system types are. For covered solar thermal collectors in Switzerland $450 \mathrm{kWh} / \mathrm{m}^{2}$ to $590 \mathrm{kWh} / \mathrm{m}^{2} \mathrm{can}$ be assumed, with uncovered collectors $300 \mathrm{kWh} / \mathrm{m}^{2}$ to $400 \mathrm{kWh} / \mathrm{m}^{2}$ (Hostettler 2020). Figure 2 shows DHW systems with an area specific thermal yield of up to $700 \mathrm{kWh} / \mathrm{m}^{2}$ a for covered PVT collectors in a DHW system and up to $400 \mathrm{kWh} / \mathrm{m}^{2} \mathrm{a}$ of area specific thermal yield for uncovered PVT collectors.

\subsection{Solar utilisation ratio and characteristic operating temperatures}

The solar utilisation ratio (Figure 3) normalises the yield with the irradiation on the collector plane, thereby making results for systems at different locations and with different orientations of the collector field more comparable. The remaining, still large differences are mainly due to the different collector types, operation at different ambient temperatures and different operating temperatures. The latter depend in particular on the type (how the heat is used) and dimensioning (ratio between collector area and heat demand) of the system. Uncertainties for the assumed irradiation for some systems can also play a role in the differences. System 18 and 19 show particularly low thermal utilisation ratios as they are holiday houses with a very low heating demand. 


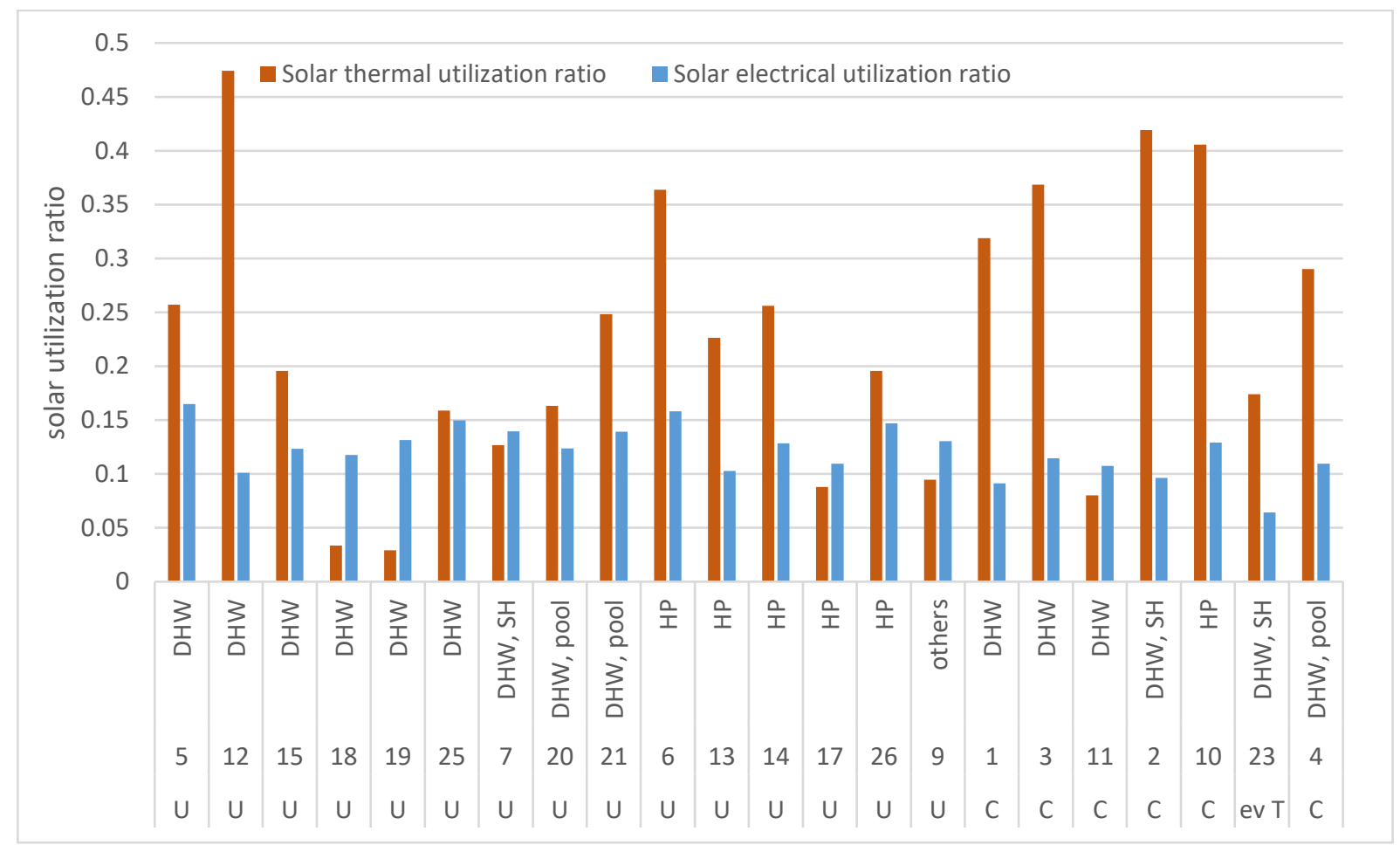

Figure 3: solar utilisation ratio for the example systems. The numbers on the $x$-axis label indicates the system number. U: uncovered PVT collectors, C: covered PVT collectors, con: concentrating collector (Solarus), ev T: evacuated tube PVT collectors.

Figure 4 shows the solar utilisation ratios as a function of the characteristic operating temperatures of the PVT fields for those example systems for which operating temperatures were available. The operating temperature of the system that was given for the example systems is an average temperature of the fluid coming to the PVT-collector. The output-weighted temperature, described in section 3.3.4 could not be considered for the example systems. Covered and uncovered PVT collectors are indicated with different colours, as covered PVT collectors are expected to have a higher efficiency due to lower thermal losses. Systems in which the average fluid temperature was unknown or not reliable are not shown in this figure (see Table 2 for data). In the case of covered PVT collectors, there are not enough reliable data points to give a tendency. For uncovered PVT collectors, however, the solar thermal utilisation ratio correlates well with the operating temperatures in the expected way. In principal, the solar electrical utilisation ratios would also be expected to decrease with increasing operating temperature, because the electrical efficiency of silicon cells decreases with increasing temperatures. This effect, however, is not displayed by the data of the example systems. It is dominated by other factors influencing the electrical utilisation ratio, like in particular different cell specifications and different optical losses (more in the case of covered collectors due to the additional glass pane). 


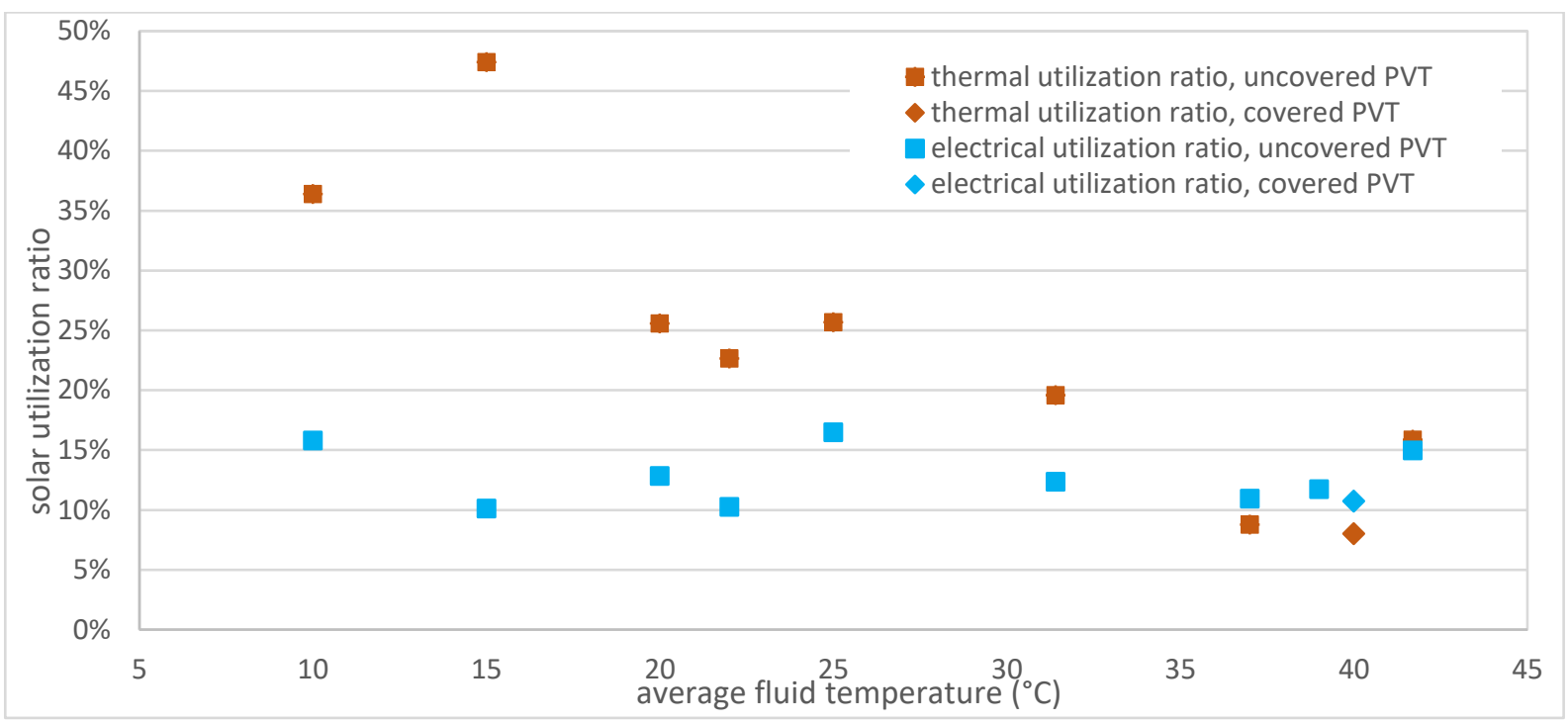

Figure 4: Temperature dependency of the solar thermal utilisation ratio (red) for the example systems divided into covered (diamond) and uncovered PVT (square). Additionally the solar electrical utilisation ratio is shown in blue for both, covered and uncovered PVT collectors.

The average solar utilisation ratios of covered and uncovered PVT collectors respectively are shown in Figure 5 . In the calculation of the averages, all systems were taken into account, including those for which the operating temperature was not known. Besides the average, the statistical distribution of the values is indicated by boxes and bars (see details in in the plot caption).

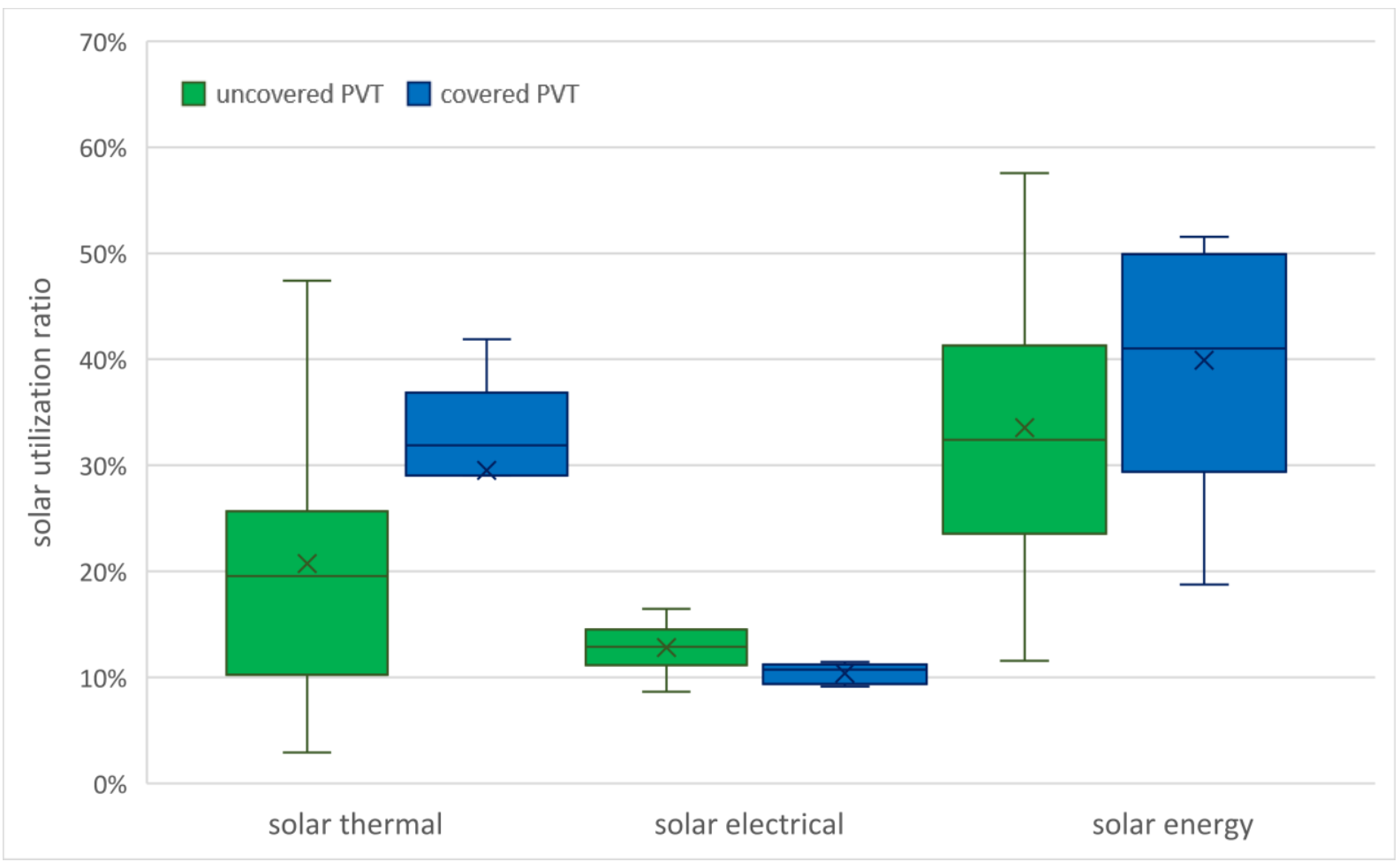

Figure 5: Average solar utilisation ratio for covered (darker colours) and uncovered (brighter colours) PVT collectors as box plots, showing the median (line within the box), the average value (cross within the box). The boxes themselves indicate the span where $50 \%$ of the values around the median are located. The whisker indicates minimum and maximum values. 


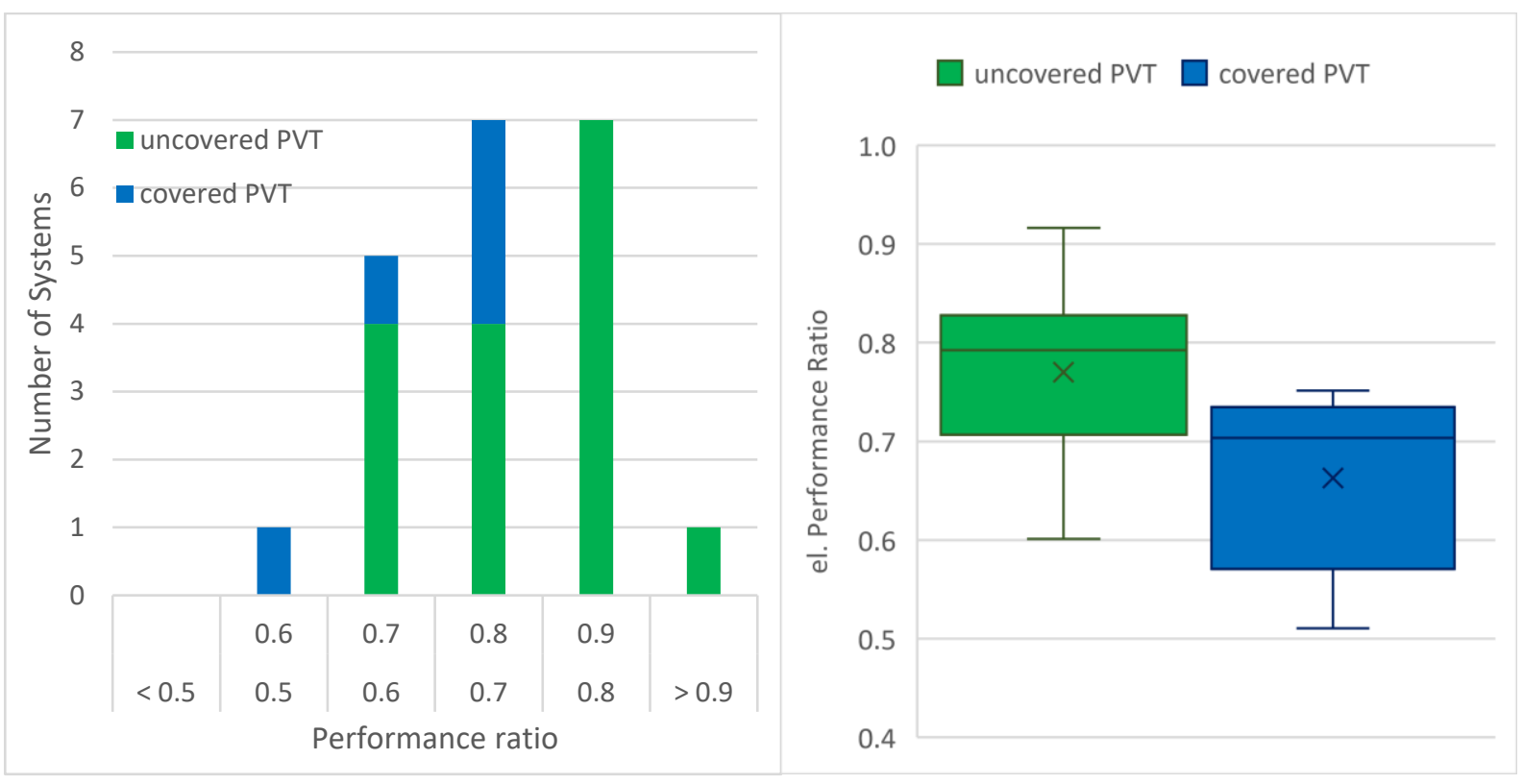

Figure 6: Histogram for electrical performance ratio. The average performance ratio for the PVT example systems is 0.74 for all systems, 0.66 for covered PVT and 0.77 for uncovered PVT (left), box plot for average and distribution of the electrical performance ratio for the different systems. The box plot shows the median (line within the box), the average value (cross within the box). The boxes themselves indicate the span where $50 \%$ of the values around the median are located. The whisker indicates minimum and maximum values.

When considering these results, one should bear in mind that the number of systems, in particular for the case of covered collectors is very small and most of them are similar systems at favourable locations. The averages should not be considered as values that would be reached by this type of PVT collectors in very diverse conditions. The maximum values, however, can serve as good indicators for what the respective collector types are capable of.

As mentioned in the previous section, the solar electrical utilisation ratio depends on the electrical specifications of the collectors (with in particular their rated power, which, in turn, depends on the cell characteristics and the optical losses of the collector). By considering the electrical performance ratio of the systems (see Figure 6), i.e. by dividing the utilisation ratio by the nominal electrical efficiency, one can factor out the differences in the electrical specifications of the PVT collectors used in the different systems. Consequently, the difference between the averages of uncovered and covered collectors reduces from around $23 \%$ when comparing the electrical utilisation ratio to around $14 \%$ when comparing the electrical performance ratio. A part of the remaining difference is most likely due to the difference in operating temperatures. If one wanted to also factor out this dependency, an option would be to consider the temperature corrected electrical performance ratio (Ventura and Tina 2016).

Figure 6 (left) shows a histogram of the electrical performance ratios of the PVT example systems. Typical values of the electrical performance ratio in the 2000s were found to lie between 0.7 and 0.85 depending on the region (Khalid et al. 2016). In a study of 1700 PV-Plants in Switzerland monitored between 2009 and 2016, the average performance ratio was 0.75 (Thomas Vontobel 2019). The average of all PVT-Systems in the present survey is 0.74 , whereas the average of covered collectors is 0.66 and the average of uncovered collectors is with 0.77 in the same range like for PV systems. The number of systems considered is, however, very low. For this reason, the given averages cannot be considered as representative for PVT systems in general. 


\subsection{Direct solar thermal fraction}

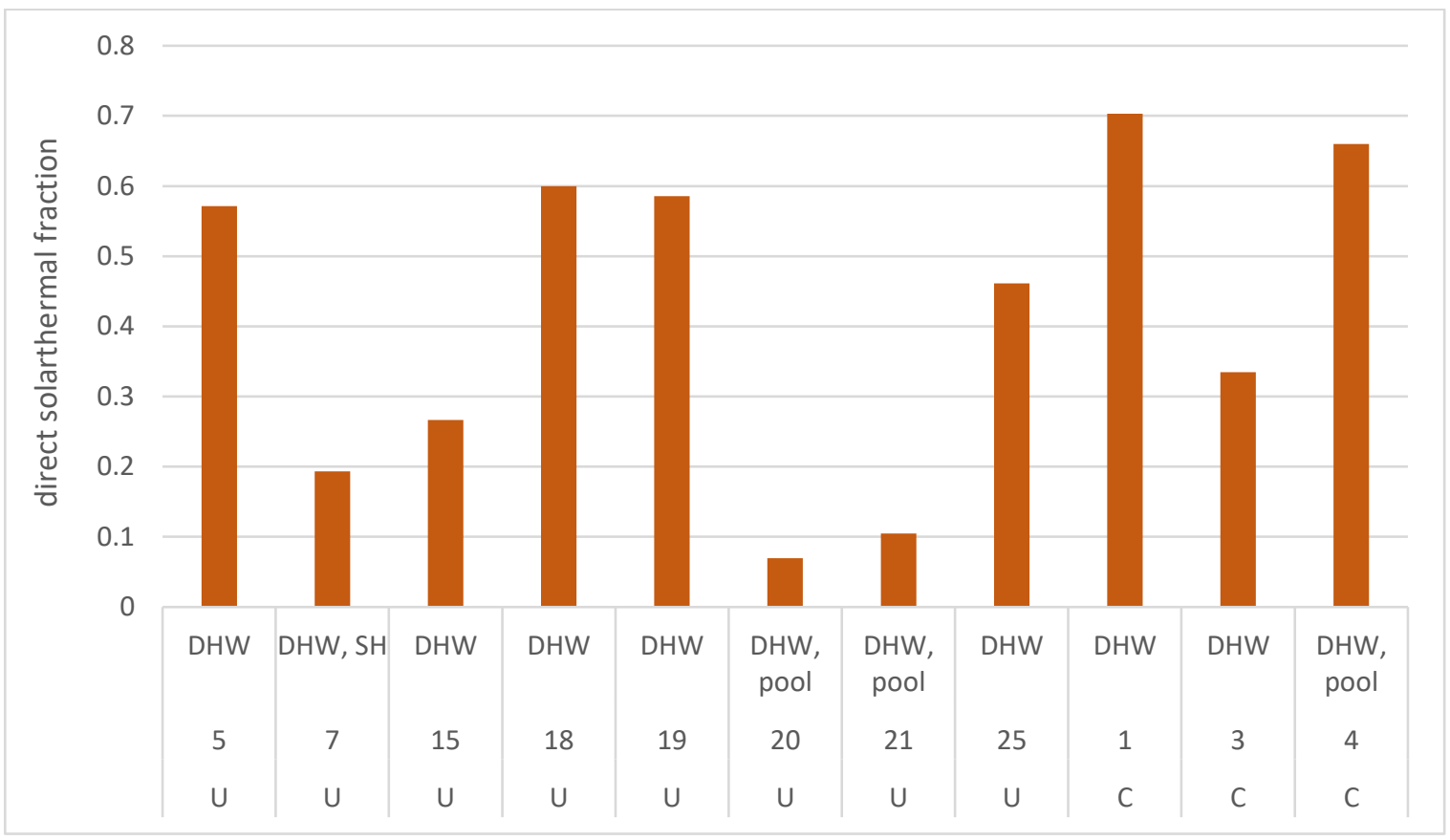

Figure 7: Direct solar-thermal fraction for systems with known amount of directly used heat from the PVT field and with known heat demand of the system. The numbers on the $x$-axis label indicate the system number. $U$ : uncovered PVT collectors, C: covered PVT collectors, con: concentrating collector (Solarus), ev T: evacuated tube PVT collectors.

The direct solar thermal fraction (Figure 7) depends on the relation between collector field area and the heat demand of the system. The differences between the systems is huge, but values above $60 \%$ are reachable depending on system integration, system dimensioning and climatic conditions. The two systems (20 and 21) with very low direct solar thermal fraction around 0.1 are municipal swimming pools, with a very high heat demand compared to the collector field area.

\subsection{Seasonal performance factor of heat pump systems}

For systems with a heat pump, the seasonal performance factor (SPF) gives information about the performance of the system as a whole. The collection of example systems contains reliable data for the SPF calculation for only four systems (Figure 8 ). The seasonal system performance factor is larger than 2.5 for all four systems. 


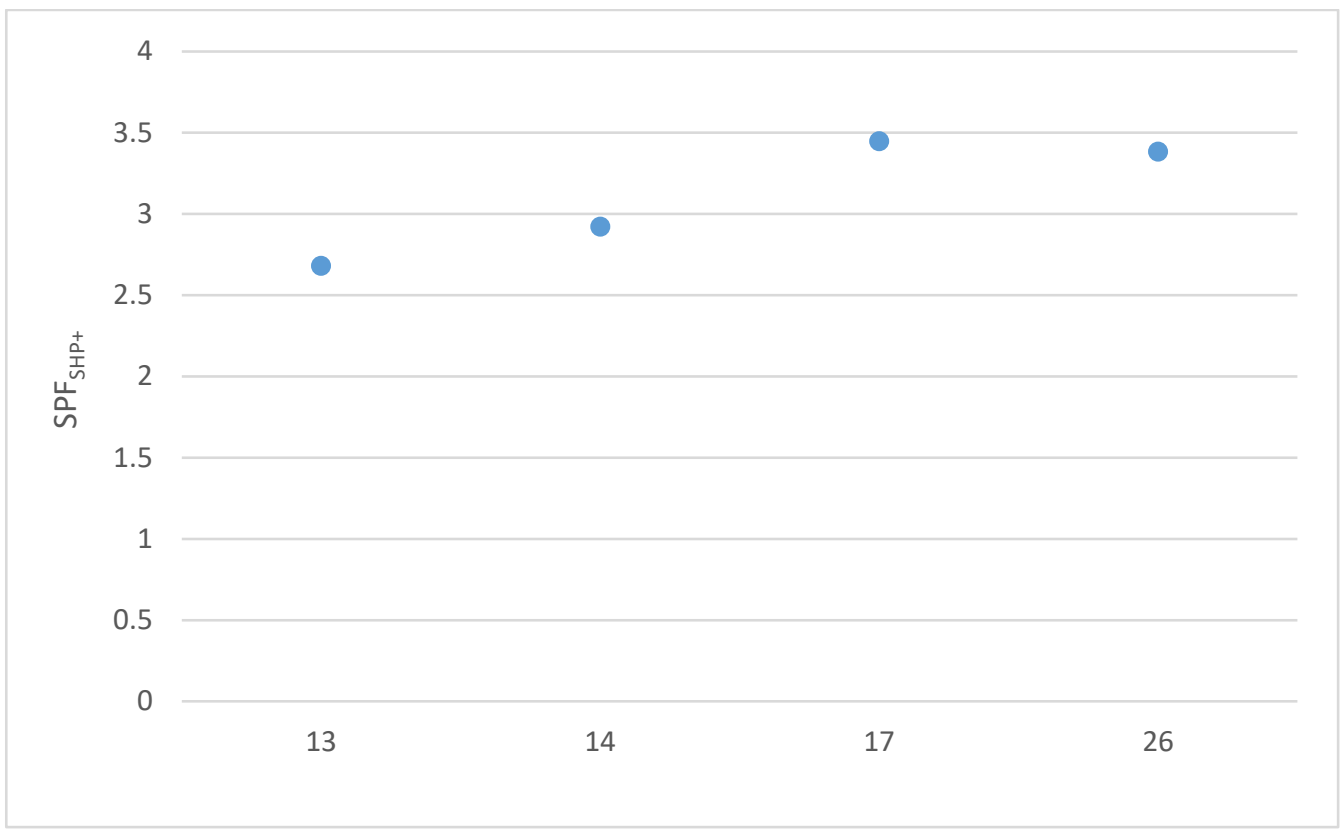

Figure 8: Seasonal performance factor for the whole system for three systems with PVT as source of a heat pump.

\subsection{Costs of heat, electricity and installation}

Figure 9 shows the levelised costs of heat and electricity. Test sites are not considered because the costs for test sites are not realistic for the market. As the electrical yield is much lower than the thermal yield, the levelised costs for electrical energy are higher in most cases. Some systems show very high overall costs or high costs for the thermal part. As most of the systems are pilot projects the costs are not always meaningful for getting a good estimate of costs for PV-systems, but they show that below $0.1 \mathrm{EUR} / \mathrm{kWh}$ for thermal and about $0.2 \mathrm{EUR} / \mathrm{kWh}$ for electrical energy are possible with PVT-Systems. The averages of levelised costs for covered and uncovered PVT collectors are shown in Figure 10. Systems with uncovered PVT-collectors seem to have higher levelised costs than systems with covered PVT-collectors, but this might be an effect of the default division of costs for most of the systems. If the real costs for thermal and electrical part of the system was not stated, $2 / 3^{\text {rd }}$ of the total costs were counted for thermal part, $1 / 3^{\text {rd }}$ for electrical part of the system (see Table 2). Lämmle, (2019) calculated levelised costs for PVT systems to be $0.22 \mathrm{EUR} / \mathrm{kWh}$ for heat and $0.2 \mathrm{EUR} / \mathrm{kWh}$ for electricity. The average of LCOH that was found in the example systems in Task 60 is about $0.45 \mathrm{EUR} / \mathrm{kWh}$ in case of uncovered, $0.25 \mathrm{EUR} / \mathrm{kWh}$ for covered PVT collectors and are therefore higher than in the study of Lämmle (2019). The average value LCOE of the example systems of Task 60 is with about $0.1 \mathrm{EUR} / \mathrm{kWh}$ for uncovered and $0.15 \mathrm{EUR} / \mathrm{kWh}$ below the value calculated from Lämmle (2019). The default assumptions for splitting the costs to thermal and electrical part seems to lead to a shift of costs to the thermal part and therefore a higher $\mathrm{LCOH}$. Additionally, different systems show a huge variation of the levelised costs. System 18 and 19 for example have very high Values of LCOH as these systems have a very low heating demand as they are operating only a few weeks per year. Figure 9 shows that a lot of systems have levelised costs that are in the range of the findings of Lämmle (2019) or even below.

For rooftop PV systems within the European Union a special distribution of the levelised costs of electricity has been published in the PV Status Report 2019 (Jäger-Waldau 2019). The LCOE ranges from 0.06 EUR/kWh in the very south of Europe to $0.32 \mathrm{EUR} / \mathrm{kWh}$ in the very north. It varies from north to south because of different amount of irradiation and additionally from country to country because of different costs. Levelised costs of heat for solarthermal systems for domestic hot water production range from $0.03 \mathrm{EUR} / \mathrm{kWh}$ systems in southern Europe to 0.19 EUR/kWh in central and northern Europe (ESTIF 2015). Figure 9 shows that several systems reach the same range of levelised costs as determined for conventional solar-thermal systems and PV systems (e.g. systems 1, 4, 6, 26, 20, 21). 


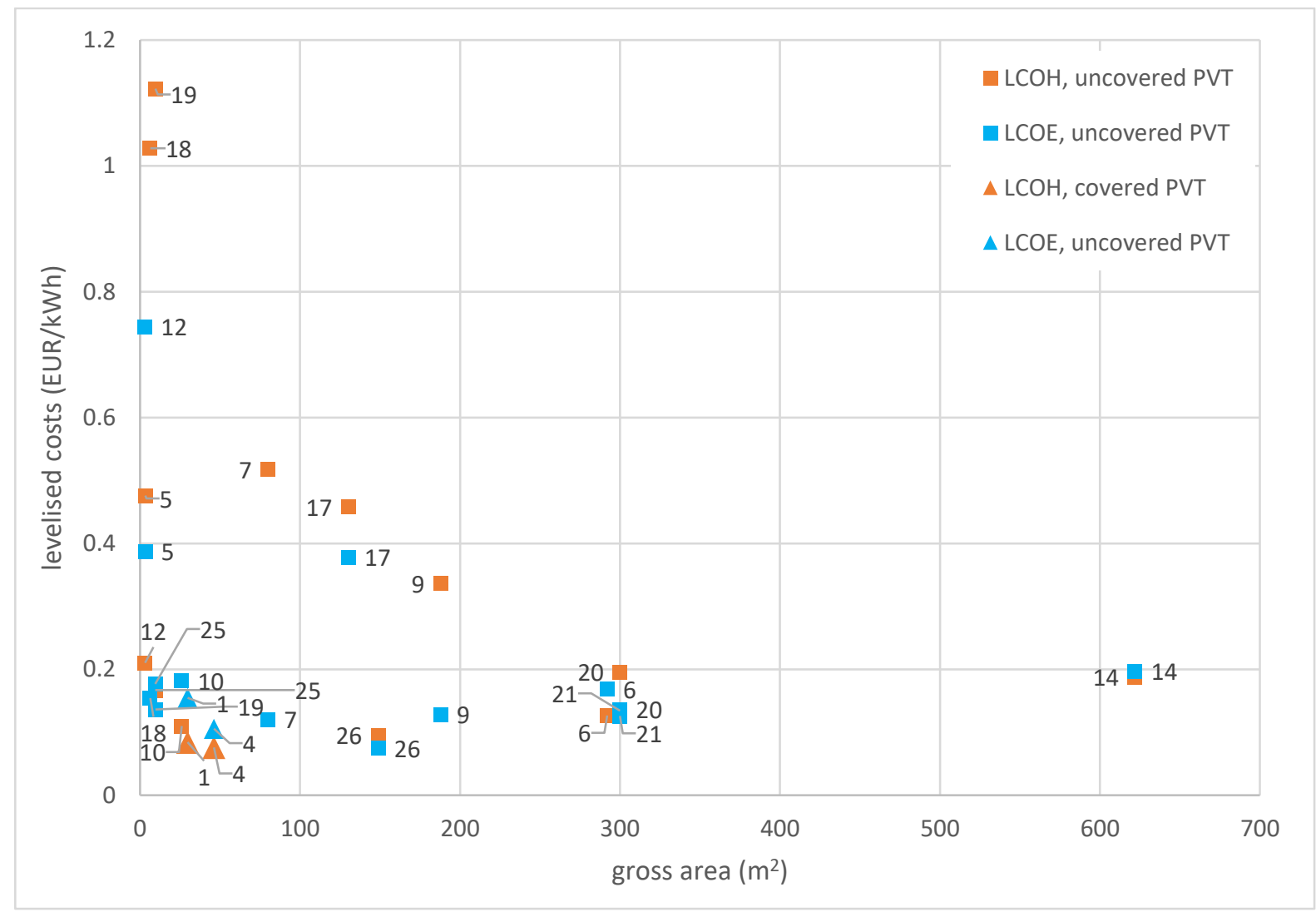

Figure 9: Levelised costs for thermal and electric energy related to the size of the collector field (Test and lab projects not shown). The numbers are indicating the system number.

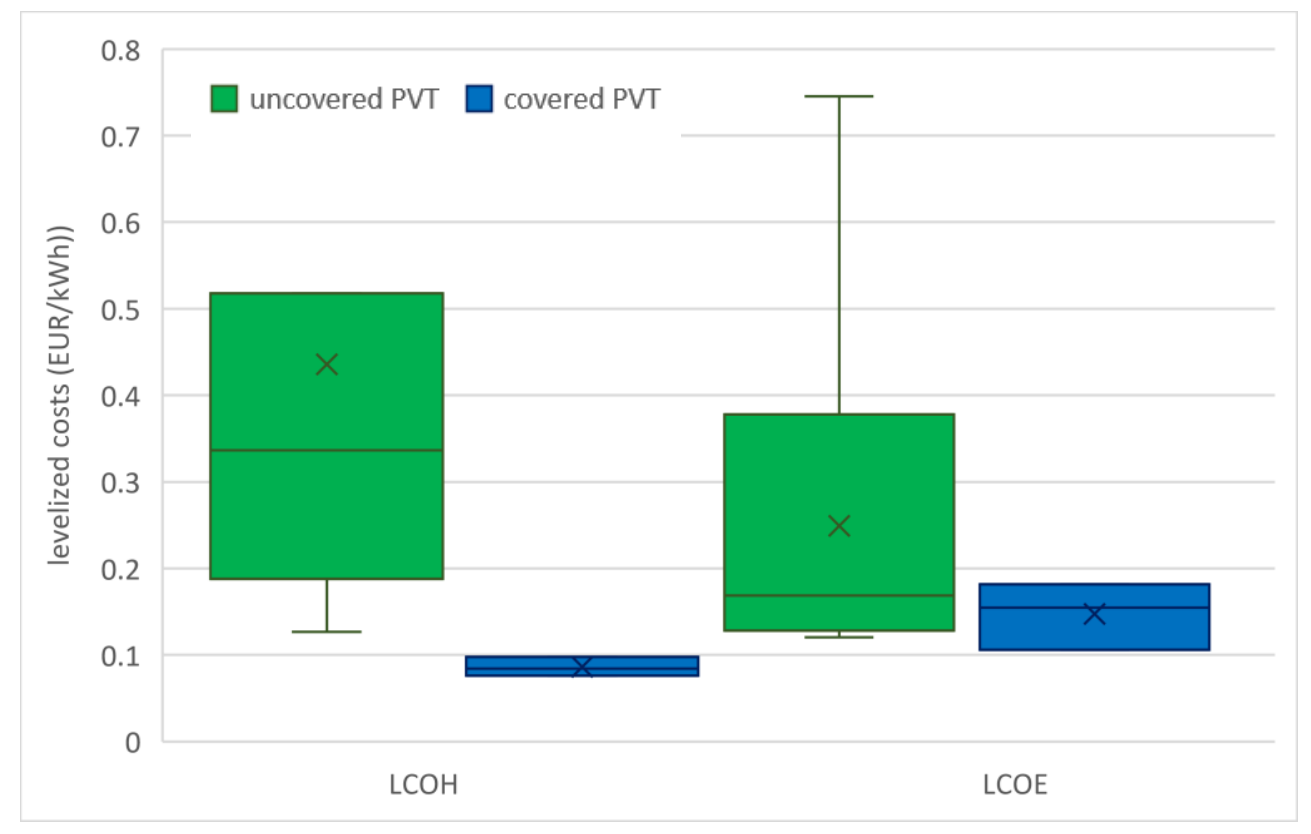

Figure 10: Average and value distribution of levelised costs of electricity (LOCE) and heat (LOCH) for covered and uncovered PVT projects as box plot. The box plot shows the median (line within the box), the average value (cross within the box). The boxes themselves indicate the span where $50 \%$ of the values around the median are located. The whisker indicates minimum and maximum values. 
To value the differences between systems with covered and uncovered PVT-collectors regarding the levelised costs Figure 11 shows the investment costs per square meter. In the investment costs, not considering the yield and the operating costs, the systems with uncovered PVT-collectors are in a similar range than covered PVT - collectors. Having only reliable cost data for two systems with covered PVT collectors, these data are not very representative for the market. The investment costs are varying by $300 \%$ (excluding system 5). A possible explanation for this variation is that some systems still have the character of a pilot plant, which leads to higher costs typically. Additionally the data comes from systems from different countries with different costs of work.

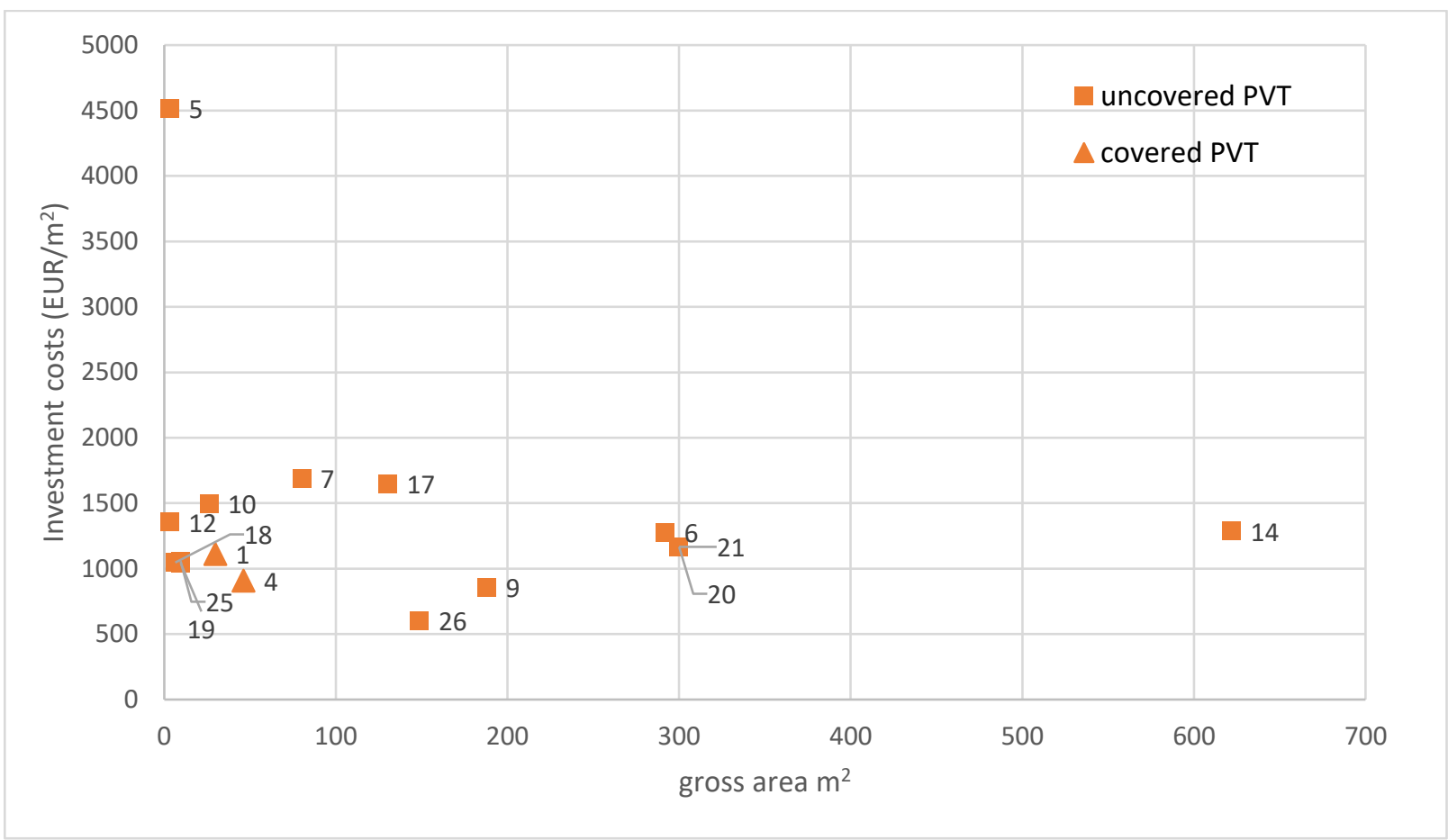

Figure 11: Total Investment costs per $m^{2}$ compared with the gross area of the PVT-plant. The numbers are indicating the system number.

\subsection{Saved fuel costs}

In the decision process for a heating system, investment costs and annual costs are still one of the most important factors for stakeholders. Figure 12 shows the annually saved fuel costs. The average for the systems with available data is about $22 \mathrm{EUR} / \mathrm{m}^{2} \mathrm{a}$. Therefore higher investment costs of about $550 \mathrm{EUR} / \mathrm{m}^{2}$ are covered by saved fuel costs. Depending on local feed in tariffs and prices for electricity, oil and gas, this value might vary a lot from case to case. The self-consumption was not evaluated for most of the systems and assumed to be $20 \%$, which is rather low. With a higher self-consumption rate the savings can be higher (depending on the local tariffs). Additionally several countries have subsidies for renewable energies that are not considered here but can help to make PVT systems competitive to fuel systems. 


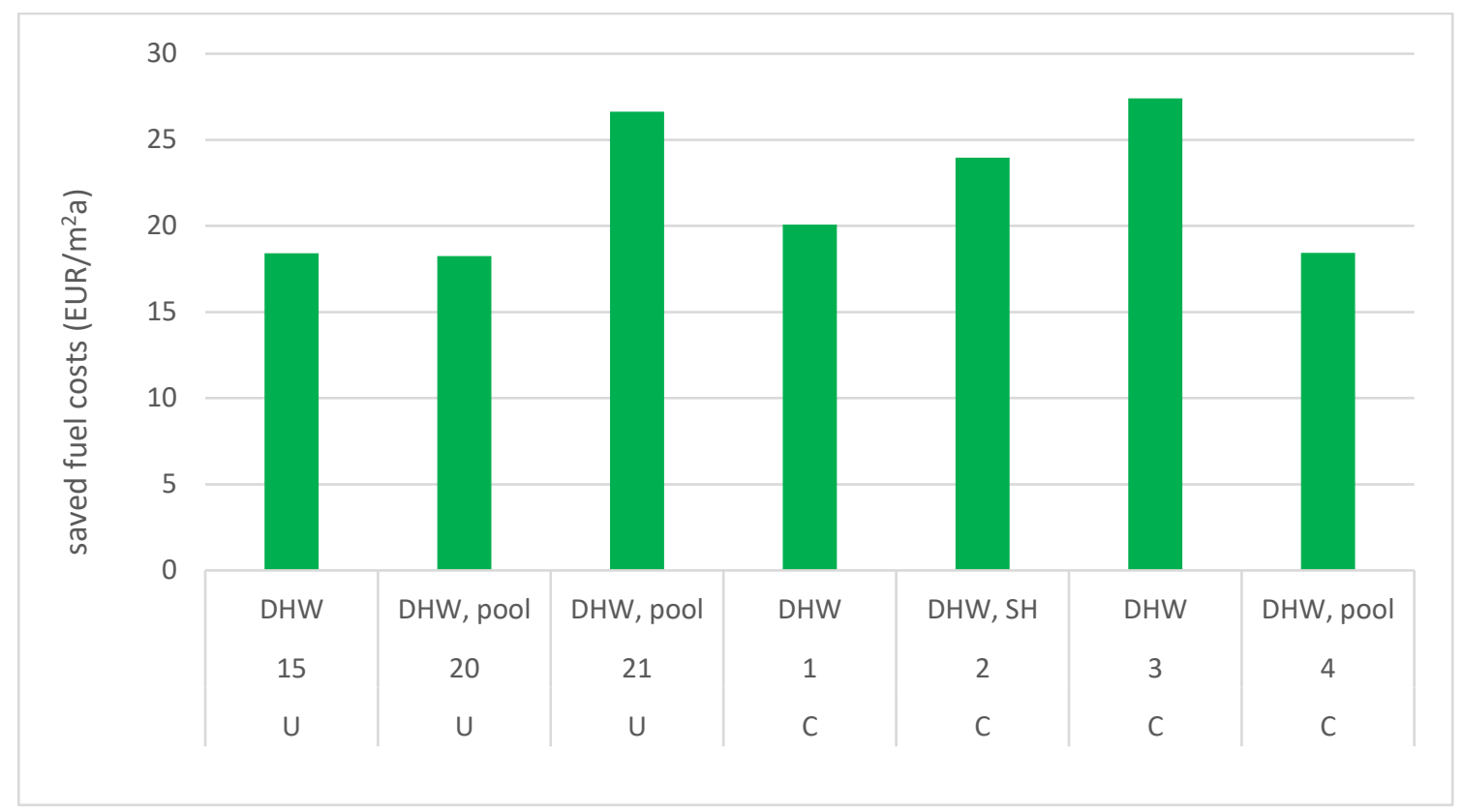

Figure 12: Saved fuel costs for the systems where data was available.

\subsection{Avoided global warming potential}

Figure 13 shows the global warming potential that was avoided in the PVT-system per year. The self-consumption of electricity was not measured for most of the systems, but assumed to be $20 \%$ of the electrical (AC) annual yield. For replacement of fuel a burner efficiency of $90 \%$ was assumed (if not assigned differently in the survey). For heat pump-systems we assumed a COP of the heat pump of 3 . The Average of the avoided global warming potential for the analysed systems is about $130 \mathrm{kgCO}_{2}-\mathrm{eq} / \mathrm{m}^{2} \mathrm{a}$. This results into a reduction of 2.6 tons of $\mathrm{CO}_{2}$-eq per year. for a system with a PVT-gross area of $20 \mathrm{~m}^{2}$.

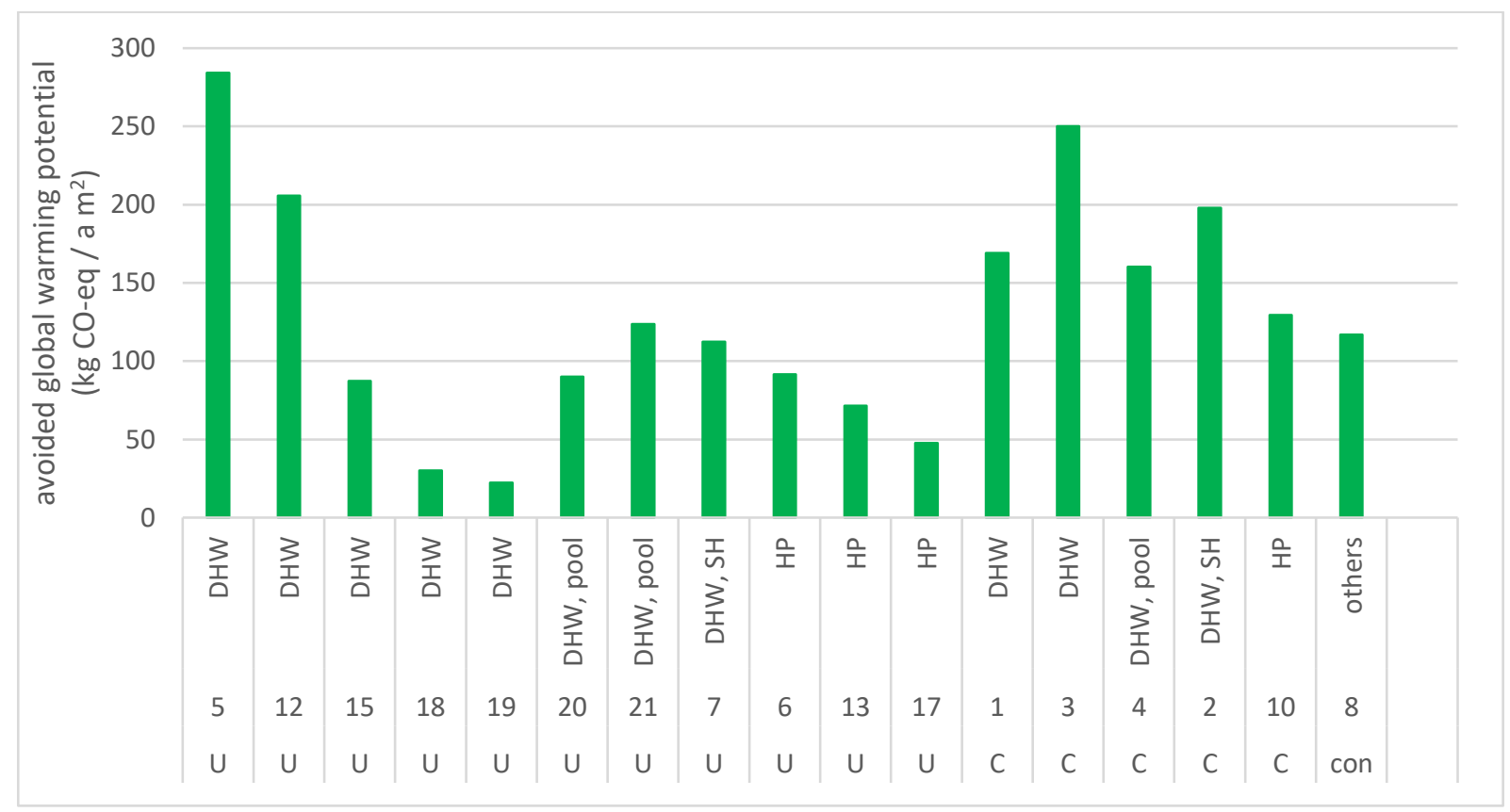

Figure 13: Avoided global warming potential for the example systems. U: uncovered PVT collectors, C: covered PVT collectors, ev T: evacuated tube PVT collectors.

Systems 18 and 19 did not replace much energy by renewables as they are holiday houses with a very low electricity and heat demand. They are in that respect not representative PVT systems. 
For getting information about the control strategies that are applied in the example systems, a survey was sent to all contributors. The survey was filled out for six of the example systems (PVT systems for domestic hot water, a PVT - heat pump system and an air PVT system). The following sections contain the questions asked together with the summarised answers.

\section{Question 1:}

Please describe in a few words the control strategy of the system, i.e. possible operation modes of the main components, conditions for them to occur (temperature levels, ...), priorities etc.

For the case of the heat pump system, it was pointed out that the priority was set to heating the domestic hot water tank directly. Second priority was PVT as source for the heat pump.

For domestic hot water systems, control strategies were either based on the temperature difference between outlet and inlet of the PVT field, or as is common in solar thermal systems, on the temperature difference between the collector outlet and the heat storage tank (e.g. "on" if T_PVT_out > T_tank_bottom + $6 \mathrm{~K}$ and "off" if T_PVT_out $<$ T_tank_bottom + $2 \mathrm{~K}$ ).

For the air - PVT system, it was reported that it is controlled by using a "light" version of a commercial control.

\section{Question 2:}

Do you use advanced control strategies? (load-shifting, predictive control (using weather and load profiles, feed-in tariffs) , artificial neural networks, fuzzy logics, ...) If yes, please add a short explanation.

No one uses such advanced control strategies yet, but some are planning to use them in the future (using e.g. weather / load profiles, feed in tariffs).

\section{Question 3:}

\section{How is the control strategy implemented (what kind of hardware)?}

Different controllers were mentioned:

- $\quad$ Commercial delta T controllers like for solar-thermal systems (i.e. PAW SC3.6, Resol)

- Overall plant supervision (Siemens RLU220)

\section{Question 4:}

\section{Is there any aspect of the control strategy that is specific for a PVT system?}

Thinking of electrical and thermal systems as a whole and optimising it as one system was mentioned as an aspect of PVT specific control for domestic hot water systems as well as for PVT-heat pump systems. Another aspect is a lower overheating prevention limit than for a solar-thermal system to prevent damage on the PV cells $\left(80^{\circ} \mathrm{C}\right.$ for that PVT System).

\section{Question 5:}

\section{How (on what basis) was the control strategy defined?}

For some of the systems the parameters were set by the system operator/customer. Others tried to develop their system to be adaptable to standard solar-thermal controller and PV converters or to standard heat pumps.

\section{Question 6:}

\section{Do you see potential for optimisation of the control strategy? If yes, please describe.}

For all systems this question was answered with "yes". The common goal is to optimise the system, whereby the goals of optimisation may vary: yield in terms of energy, thermal comfort, financial or environmental outcomes. To reach such goals of optimisation the system should be optimised as a whole and needs therefore a control strategy that takes the interaction between different system parts into account. Especially for complex systems 
like PVT-heat pump systems, this is a difficult issue. Prediction of needs (thermal, electrical) and solar availability and adaptive control strategies have been proposed to fulfill the goal of optimisation.

\section{Question 7:}

\section{Can you give general recommendations on control strategies for PVT systems?}

This question turned out to be difficult to answer, as the systems are very diverse. For air PVT systems, the lower inertial times (compared to liquid based systems) were mentioned. The system responds much quicker to the control system inputs settings. For PVT - heat pump systems a control strategy for the system as a whole is crucial to reach a good system performance.

\section{Question 8:}

What is the strategy for failure detection (e.g. of pressure drop, pump failure...)? Is there for example an automatic alert system, or do you do regular on-site inspections?

For the PVT - heat pump system there is an alert for abnormal stop of the heat pump at temperatures of the source above $-5^{\circ} \mathrm{C}$ as this may be linked to a leak or a clogged filter. For the PVT-system, themselves often temperature alarms are used (maximum temperature and freezing prevention). Additionally pressure drop alerts are used, flow-rate related alerts respectively for PVT-collectors made of polymeric material (relaxation covers pressure drops).

\section{Question 9:}

\section{Are thermal and electrical yields monitored and who looks at the data and how often?}

The monitoring periods reach from data logged every 30 seconds to weekly or monthly data monitoring by the customer. The processing of the monitored data reaches from weekly to yearly and is done by the installer or by the PVT manufacturer.

\section{Question 10:}

\section{Is there a strategy for operation optimisation (manual/automatic), and with which optimisation target?}

None of the systems is optimised using a certain automatic strategy. For most of the systems the parameters for optimisation (e.g. band gaps of the hysteresis or temperature levels) are set manually by the installer, the operator or the PVT manufacturer.

\section{Question 11:}

Who is responsible for surveillance, optimisation?

Very diverse from operator himself or herself being responsible to installer or $3^{\text {rd }}$ party companies.

\section{Question 12}

What problems with system operation and control have been encountered? Which improvements have been made during operation? Lessons learned?

The bandwidth of problems with the PVT example systems is quite large. For the heat pump system one problem was that the control of the heat pump was not open and a technician from the heat pump company had to be on site to modify control settings. Further, several kinds of communication problems either of human nature, information did not reach the right person, or of technical nature, due to non-reliable wifi connections or electrical cuts that reset important parameters. Others mentioned technical problems within the PVT system like air bubbles blocking valves or leakages. Additionally, problems like shadowing due to growing trees, damaged PV modules and vandalism were mentioned.

\section{Question 13:}

\section{Are high stagnation temperatures an issue/risk? If yes, what is the strategy to control/prevent it?}

Depending on the type of collector. Some are designed to have stagnation temperatures of about $80^{\circ} \mathrm{C}$, for others there is a risk of boiling fluid or PV cell damage that has to be prevented by the control strategy. 


\section{Conclusion}

Several KPIs were determined for the 26 PVT example cases collected in the IEA-SHC Task 60. The results are very diverse due to the diversity of the systems; from pure generation of domestic hot water in warm countries up to the support of heat pump systems in rather could regions. The number of systems was too small to make proper statistical analyses and a direct comparison has a limited informative value due to the diversity of the systems. Nevertheless, the KPI analyses show that PVT systems can reach a good performance. Systems for direct production of domestic hot water with covered PVT collectors can reach a direct solar thermal fraction of up to $70 \%$ in warm climatic conditions. Heat pump systems with uncovered PVT collectors as their main heat source can reach an annual system SPF of about 3 in Switzerland. Well-dimensioned systems can reach levelised costs of about 0.2 EUR/kWh for electricity and $0.1 \mathrm{EUR} / \mathrm{kWh}$ for heat. Therefore, these systems reach levelised costs of electricity comparable to literature values of PV systems and levelised costs of heat comparable to literature values of solarthermal systems (ESTIF 2015; Jäger-Waldau 2019). For covered PVT collectors the electrical performance ratio shows with 0.66 a slightly lower average value than the average of PV systems in different regions (0.7-0.85, Khalid et al. (2016)). Due to their lower operating temperatures, uncovered PVT collectors have a higher electrical performance ratio; the average of the considered PVT example cases is 0.75 . With about $700 \mathrm{kWh} / \mathrm{m}^{2}$ for covered and about $400 \mathrm{kWh} / \mathrm{m}^{2}$ for uncovered PVT collectors the annual area specific yield of some of the PVT example systems is in the range of the yield of pure solar-thermal systems (Hostettler 2020). The analyses of KPIs of the PVT example cases show that a well-dimensioned PVT system can reach a good energetic performance as well as economically viable costs for energy production.

The control strategies for the example systems are very diverse due to the diversity of the systems. For PVT systems with direct use of the heat for domestic hot water production, the control strategy is similar to solarthermal systems and there are no specific differences for PVT except the lower stagnation temperatures. In heat pump systems with PVT as a source for the heat pump, the control strategy for the heating system is more complex, but not very different from the case of an equivalent system with solar thermal collectors plus PV modules. The contributors see the optimisation of the energy yield and the minimisation of the costs as optimisation goals. To reach an overall optimisation for the whole PVT system the control strategy should consider the system as a whole and not consider the different system parts separately. 


\section{Bibliography}

Daniel Zenhäusern. in prep. 'Key Performance Indicators'. SHC Task 60 Report D1.

ESTIF. 2015. 'Solar Thermal Contribuition to the EU Strategy for Heating and Cooling'. European Solar Thermal Industry Federation (ESTIF). https://www.solarthermalworld.org/sites/gstec/files/news/file/2015-1220/estif_comments_on_questions_september_2015.pdf.

Hadorn, Jean-Christophe, and Task 44 'Solar and Heat Pump Systems' (Project), eds. 2015. Solar and Heat Pump Systems for Residential Buildings. First edition. Berlin, Germany: Ernst \& Sohn.

Hostettler, Thomas. 2020. 'Markterhebung Sonnenenergie 2019'. Bundesamt für Energie. https://www.swissolar.ch/fileadmin/user_upload/Markterhebung/Marktumfrage_2019.pdf.

Jäger-Waldau, Arnulf. 2019. 'PV Status Report 2019'. European Commission. https://ec.europa.eu/jrc/sites/jrcsh/files/kjna29938enn_1.pdf.

Khalid, Ahmad Mohd, Indradip Mitra, Werner Warmuth, and Volker Schacht. 2016. 'Performance Ratio Crucial Parameter for Grid Connected PV Plants'. Renewable and Sustainable Energy Reviews 65 (November): 1139-58. https://doi.org/10.1016/j.rser.2016.07.066.

Koordinationskonferenz der Bau- und Liegenschaftsorgane der öffentlichen Bauherren KBOB, ed. 2016. 'Ökobilanzdaten Im Baubereich 2009/1:2016'. https://www.kbob.admin.ch/kbob/de/home/publikationen/nachhaltigesbauen/oekobilanzdaten_baubereich.html.

Lämmle, Manuel, Fraunhofer IRB-Verlag, and Freiburg/Brsg Fraunhofer ISE. 2019. 'Thermal Management of PVT Collectors Development and Modelling of Highly Efficient Glazed, Flat Plate PVT Collectors with Low Emissivity Coatings and Overheating Protection'.

Thomas Ramschak, Aleksis Baggenstos (SPF), Alexander Mellor (Naked Energy), Antonio Gagliano (UNICT), Carsten Corino (Sunoyster), Daniel Zenhäusern (SPF), Diogo Cabral (Solarus), Glen Ryan (Sunovate), et al. 2020. 'Collection of Data Sheet on Existing PVT Systems and Solutions'. SHC Task 60 Report A1.

Thomas Vontobel. 2019. 'Performance von PV-Anlagen unter der Lupe'. bulletin.ch 10/2019, 10 February 2019. https://www.bulletin.ch/de/news-detail/performance-von-pv-anlagen-unter-der-lupe.html.

Ventura, Cristina, and Giuseppe Marco Tina. 2016. 'Utility Scale Photovoltaic Plant Indices and Models for OnLine Monitoring and Fault Detection Purposes’. Electric Power Systems Research 136 (July): 43-56. https://doi.org/10.1016/j.epsr.2016.02.006.

Weiss, Werner, and Monika Spörk-Dür. 2020. 'Solar Heat Worldwide - Global Marked Development and Trends in 2019'. AEE INTEC. https://www.iea-shc.org/Data/Sites/1/publications/Solar-HeatWorldwide-2020.pdf. 